\title{
DVORY, DVORCE NEBO SÍDLA - K OTÁZCE SOCIÁLNÍHO VYMEZENÍ ELIT VE STŘEDOVĚKU
}

\author{
DAVID NOVÁK
}

\begin{abstract}
Abstrakt: Středověká společnost sestávala ze širokého spektra sociálních skupin, které byly specifické svými artefaktuálními projevy. Je pravděpodobné, že možnost disponovat určitým predmétem či obývat konkrétni typy staveb pomáhala definovat postavení jedinců i komunit a symbolicky vyjadřovat jejich společenské postavení. Vertikálni, horizontální i formální vymezení sloužilo jako prostředek symbolické komunikace, který stabilizoval vztahy v komunitě. Přispěvek se zabývá otázkou, nakolik se tento fenomén projevuje $v$ archeologicky dokumentovaných stavbách na pomezi sidel a dvorů a zda lze z konkrétnich stavebnich forem usuzovat na zařazeni jejich vlastnika či obyvatele mezi středověké elity.
\end{abstract}

Klíčová slova: hospodářský dvůr - špýchar - sýpka - věžovitá stavba-sídlo.

\section{Manorial farms, curias and seats: the issues of social definition of elites in the Middle Ages}

Abstract: Medieval society consisted of a wide spectrum of social groups characterised by specific artefacts. It can be presumed that the handling of particular objects and the occupation of particular types of buildings helped define the status of both individuals and communities and symbolised their social status. The vertical, horizontal and formal definition served as a means of symbolic communication stabilizing the relations in communities. This contribution discusses to what extent this phenomenon is manifested in archeologically documented constructions between seats and manorial farms, and whether particular building forms allow the classification of the owners or occupants with medieval elites.

Key words: manorial farm - warehouse - granary - tower-shaped building - seat.

\section{Úvod}

Zkoumáme-li vrchnostenská sídla, naše poznání značně klesá s kvalitou provedení, kterého tyto objekty dosahovaly. Málo popsanou kapitolou jsou tak středověké lokality na pomezí sídla a dvora, které byly dosud sledovány zcela okrajově. Přitom v poslední době se objevuje řada dokumentovaných lokalit, které mohou pomoci se v problematice zorientovat. Interpretace jsou prozatím poměrně jednostranně zaměřeny na ekonomické stránky takových lokalit a jejich chápání jako hospodářských dvorů a př́iliš se nevěnují reprezentačnímu a rezidenčnímu významu staveb, které se ve dvorech mohly nacházet. Lze v takových případech hovořit o vrchnostenských sídlech? Prozkoumejme toto téma na několika př́íkladech, kde ve dvoře nebo při dvoře identifikujeme věžovité stavby, které by bylo možné důvodně spojovat s vyšším sociálním prostředím.

Na úvod je třeba poznamenat, že průkaznost přítomnosti věžovitých objektů je u archeologizovaných staveb vždy problematická. Zejména v případě těch povrchově zkoumaných je proto nutné počítat s možností chybné interpretace. Často lze rozlišit pouze patrové a př́izemní objekty, avšak přesná výška budov zůstává neznámá. Indikátorem věžovitých budov je tak zejména jejich půdorys a přítomnost nadzemních reliktů, které indikují podezdívky či zdivo svou mocností neodpovídající přízemní zástavbě. U objektů prozkoumaných odkryvem pomáhají při interpretaci nálezy z destruovaných vyšších pater, jako jsou pozůstatky stropů, podlah, střešních krytin i vnitřního vybavení. Tento obraz doplňují nečetné analogie ve formě částečně dochovaných staveb, historické popisy a ikonografické prameny.

Obě poslední kategorie bohužel přímo pro v př́íspěvku popisované objekty hodnotit nelze, nebot' se o vlastní podobě dvorů nezmiňují a obvykle chybí zcela. Podíváme-li se jinam, za zmínku stojí chronologicky i prostorově poněkud vzdálenější, přesto velmi sugestivní popis franckých dvorů 9. století, sepsaný jako inventarizační zpráva a zpř́ístupněný českému čtenáři P. Medunou (2008). Zaujme zde výčet typů ohrazení dvora, které je jednoduché dřevěné (palisáda, plot) nebo kamenné (zed'), někdy v kombinaci (kamenná brána). Částečně snad může být 
tvořeno i živým plotem. Brány bývají opatřeny ochozy „k vydáváni přikazưu“. Ohrazení může zvlášt' vydělovat i specifické části dvora - např́íklad dvorek s ovocnými stromy. Počet staveb odpovídá raně středověkému velkostatku a je vyšší než u mladších dvorů. I přesto byla jejich movitá výbava nevelká a výnosy tristní (1,5-1,8násobek úrody). Dvory ale byly v průběhu středověku patrně považovány za natolik utilitární objekty, že popis jejich formální podoby nebyl považován za hodný zmínky. V domácích pramenech se s nimi sice setkáváme od 12. století, ale popisy se objevují výjimečně až po roce 1300 , kdy v hrubých rysech postihují výčet funkčních jednotek (Novák 2016, 132).

Obecně k rozhojnění podobných pramenů dochází až od 16. století, kdy jako součást inventářů sídel bývá zmíněn i poplužní dvůr. Tehdy se objevují popisy celých komplexů: „zámek $s$ dvorem poplužním, kopaninami, zahradami k setí, vařením, chmelnicí, sladovnou s pivovarem pod zámkem a dalším př́slušenstvím“ (Bělá pod Bezdězem, 1553; Kolektiv 1998-2005, 11), dále popisy provozů: „tvrz s dvorem, sladovnou, spilkou, pekárnou, kovárnou a ovčínem“ (Biskoupky, 1573; tamtéž, 30); ,štok o dvou světnicich, kdež předešle vrchnosti bejvaly, s ratejnou, komorami, s lochem, mličnicí, kuchyní, marštalemi pro konè, též chlívy pro hovězi a svinský dobytek" (Úloh, 1594; tamtéž, 909); „na dvoru poplužnim s poplužim, kterýž slove Pinveyt, s hamrem železným, kdež se železo dělá, s př́slušenstvím“ (Bynov, 1588; tamtéž, 59) a nakonec i podrobné popisy dvorů: „tvrz, pri též tvrzi byl dvi̊r se staveními, chlévy, maštalemi, stájemi, stodolami, zahradami, ovčinem, ovčárnou a to vše v témž obojím zavření jest" (Rudník, 1615; tamtéž, 655); „tvrz Vosek - štok z kamene vystavěný se všemi pokoji klenutými, sklepy, komorami, lodžii, kuchyní, pekárnou - což ten celý štok z gruntu až po střechu ve všem zavretý v sobě od v̌̌edských pokojův obsahuje (...) před tvrzi byly maštale pro kočovské, jízdni a dělné koně, sejpka na obilí, ve dvoře ratejna, vinopalna se čtyřmi komorami, chlévy pro krávy i jalovice, chlévy sviňské se táhly až ke stodolám před dvůr" (Osek u Rokycan, 1661; Anderle-Švábek 1992, 13-14).

Datací jsou však všechny tyto zmínky zcela mimo sledovaný rámec. Písemné prameny naneštěstí ne vždy umožňují rozlišit, zda popisované provozy označují samostatné stavby, nebo zda jejich výčty (chlévy, stáje apod.) nejsou odrazem částí téže budovy. I když se jedná o cenný materiál, je proto třeba notné opatrnosti při užití písemných pramenů pro interpretaci terénních situací a při rekonstrukci podoby dvorů, zvláště středověkých.

Ikonografické prameny pak zpodobňují středověké dvory ještě vzácněji než písemnosti. Systematickou rešerší se dosud nikdo konzistentně nezabýval a jsme tak na jedné straně odkázáni na základní souhrn P. Chotěbora (1992) a případně na soupisové práce, které mnohdy obsahují i přehled dochované ikonografické dokumentace (srov. Kolektiv 1997-2005). Ta se většinou datuje do hlubokého novověku, zcela výjimečně do předbělohorského období a v jednotlivostech do středověku. Pokud se s vyobrazením sídel a přilehlých dvorů setkáváme, tak v bezejmenné formě v pozadí jiných výjevů. Obvykle ale zacházíme s prameny cizí provenience a nelze se ztotožnit $\mathrm{s}$ úvahou o naprosté přenositelnosti zobrazovaných forem např́ič Evropou (Chotěbor 1992, 177). Je třeba mít se na pozoru i před záměrnou symbolikou, která mohla významně deformovat realitu a vyzdvihovat účel obrazového sdělení (Wheatley 2004). Vyobrazení bývají často velmi schematická a upozorňuji jen na základní charakteristiky, jako např́íklad podobu ohrazení a obecné znaky budov. K souhrnu látky odkazuji k citované práci P. Chotěbora a též k další jeho kolektivní práci zaměřené př́mo na dvory (Chotěbor-Smetánka 1985).

Přes všechna zmíněná úskalí lze díky množství komplementárních př́íkladů sestavit soubor lokalit, který naznačuje zajímavé strukturální souvislosti, jež jsou předmětem následujícího rozboru. Nutně to ale bude archeologický pohled (i se všemi svými nedostatky), který při hodnocení bude převažovat. 


\section{Výzkumy sídel nejnižší kvalitativní úrovně}

Pro poznání nejnižší kvalitativní úrovně sídel je zásadní (a bohužel zároveň nedostatečně publikovaný) ${ }^{1}$ výzkum tzv. dvora Hrnčǐre (Jenišův Újezd; okr. Teplice), ${ }^{2}$ spadajícího snad mezi majetky oseckého kláštera (Meduna 2006). Odhalen byl prostor zaniklého dvora ve třech vývojově navazujících horizontech. ${ }^{3}$ Mělkým příkopem ohrazený areál o minimální rozloze $60 \times$ $130 \mathrm{~m}$ byl založen na přelomu 12. a 13. století. Obsahoval rozlehlou sýpku sloupové konstrukce a druhou, snad nedostavěnou hospodářskou stavbu. Z obytné části dvora byla zachycena dvojdílná budova, doplněná o vnější přístavek s hrnčířskou pecí a nedalekou studnu. Kromě běžných artefaktů došlo v kontextu obytné části k nálezu militarií (šipky, ostruha) a skleněné nádoby. Ve druhém horizontu dvora byla po polovině 13. století založena sladovna (Lissek 2006) a postupně zaniklo starší obvodové ohrazení. Ve třetím horizontu došlo - snad v závěru 13. století - k výrazné redukci ohrazené plochy a vymezení menšího areálu s podstatně mohutnějším příkopem $(6 \mathrm{~m}$ šíře; $2 \mathrm{~m}$ hloubky; $34 \times 46 \mathrm{~m}$; obr. 1). Př́íkop byl na vnitřní straně opatřen jednoduchým plotem. Není patrné, jak byla užita hlína vytěžená při hloubení příkopu, a nelze vyloučit existenci vnějšího valu. Vně ohrazení se v této době nacházela jedna podezděná stavba nejasné funkce $(8 \times$ $7,5 \mathrm{~m})$. V centrální části nově opevněné plochy vznikla nejdříve stavba se zahloubeným dílem a vstupní šíjí. Později byla tato stavba nahrazena dvojdílným, alespoň částečně zděným objektem o rozměrech $8 \times 14 \mathrm{~m}$. Druhou fázi stavby lze vzhledem $\mathrm{k}$ její vícedílné podobě považovat spolehlivě za obytnou. K ohrazení se v ose domu přimykala další jednoduchá stavba, snad špýchar. Do jihovýchodního nároží ohrazení byla v neznámé době doplněna budova mírně vysunutá do př́ikopu a přiléhající ke špýcharu. Nabývala věžovitého charakteru $(9 \times 5,5 \mathrm{~m})$ a v patře obsahovala keramické dláždění. Zbytky prejzů naznačují, že střecha nemusela být jen ze spalných materiáli̊. V této podobě sídlo fungovalo snad až do 15 . století, kdy nejpozději zaniklo.

Z publikovaných dat bohužel není zřejmé, zda k zániku objektů došlo současně, nebo byly opouštěny postupně spolu s výstavbou nových budov. Sledujeme však vývoj od rozsáhlého dvora směrem k menšímu areálu, který bychom bez rozpaků označili za standardní drobné vrchnostenské sídlo. Mezi ně nebývá hrnčířský dvůr obvykle řazen, a to kvůli znalosti předchozích horizontů rozsáhlé grangie. Bohaté změny dvora evokují velmi dynamický vývoj zástavby. Podobné prostorové translace byly doloženy odkryvem známého Bedřichova Světce. I tam pozorujeme prvotní zahloubený objekt se vstupní šijí, interpretovaný jako součást dřevěné fáze sídla, a v nově ohrazeném areálu mladší zděnou stavbu, jejíž přesné rozměry bohužel neznáme (odkryv byl částečný; Klápště 1994, 31-38, 149-152). P. Meduna i přes zjevně nadstandardní vybavení a přítomnost fungujícího špýcharu o nejmladší věžovité stavbě dvora Hrnčíře bez většího vysvětlení mluví jako o sýpce a ani nezvažuje její sídelní či jinou funkci (Meduna 2006, 253). V pohledu správce dvora ale mohl vznik přinejmenším patrové stavby znamenat i sociální a kvalitativní posun, který vyžadoval vybudování dostatečně reprezentativního objektu, alespoň vnějšími znaky odpovídajícího dobovým standardům vyššího sociálního prostředí, což naznačuje i ohrazení celého areálu př́íkopem. Bez lepšího vhledu do původní terénní dokumentace nelze posoudit, zda uvedená stavba sloužila přímo k obývání, nebo její role byla pouze reprezentační a symbolická. I když po celou dobu existence dvůr patrně patřil k církevním majetkům, jistě bylo v zájmu zdejšího klienta či šafáře své sídlo zvelebovat a zajištovat si tak větší společenskou váhu, at' už byl osobně svobodný (v lenním vztahu), nebo byl nesvobodným služebníkem.

Dokud máme v paměti předchozí př́íklad, zaměřme se na další ze zkoumaných lokalit, a to dvůr Rychvald (Kozojedy; okr. Rakovník). Ten i vzhledem k celkovému kontextu (jedná se snad v obou případech o klášterní dvory) autoři jeho průzkumu srovnávali s diskutovanými Hrnčíři (Kypta a kol. 2012). Nejčitelnější areál lokality je tvořen výraznou ohradou (ca $55 \times$

1 Chybí např. bližší rozbor nálezů z klíčového třetího horizontu, stejně jako jakékoli stratigrafické sekvence.

2 Lokalita v literatuře vystupuje pod dvojicí názvů - jako Jenišův Újezd (podle názvu katastrálního území) a jako Hrnčiře (podle interpretace P. Meduny). Přidržuji se druhé varianty.

3 Opomíjím pro výklad nepodstatné starši fáze osídlení lokality, kdy dvůr postupně nahradil raně středověké sídliště (srov. Bubeník-Velímský 1986). 


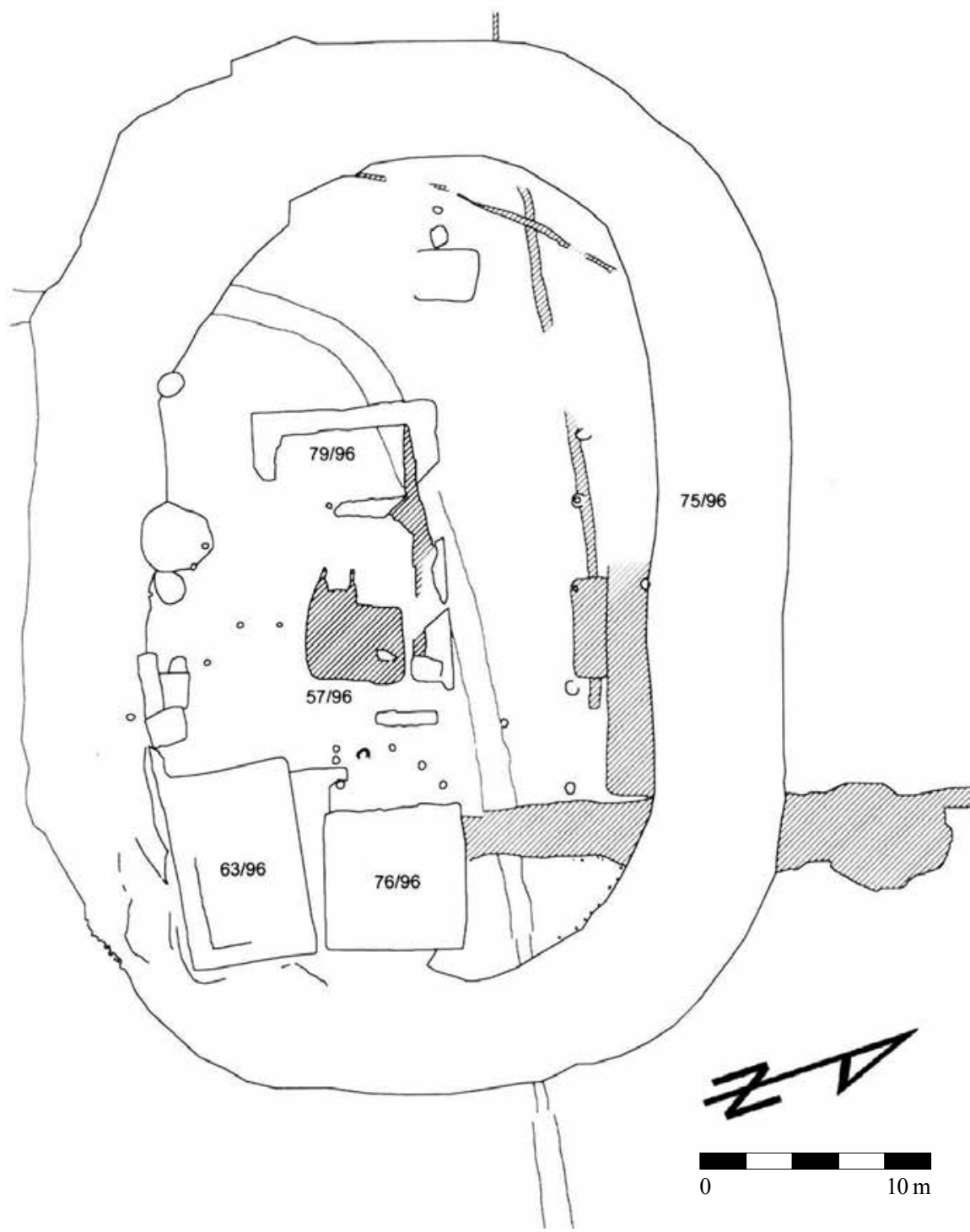

Obr. 1. Zaniklý dvůr Hrnčíře (Jenišův Újezd), třetí horizont. Zobrazeno několik fází. Diskutované objekty: 75/96 - př́íkop; $57 / 96$ a 79/96 - dvě fáze obytné stavby; 75/96 - špýchar; 63/96 - věžovitá stavba s dlážděnou podlahou vysunutá do př́íkopu. Upraveno podle Meduna 2006, 251.

Abb. 1. Hofwüstung Hrnčíře (Jenišův Újezd), dritter Horizont. Darstellung mehrerer Phasen. Diskutierte Objekte: 75/96 Graben; 57/96 und 79/96 - zwei Wohnbauphasen; 75/96 - Speicher; 63/96 - turmartiger Bau mit in den Graben reichendem Pflasterfußboden. Bearbeitet nach Meduna 2006, 251.

$50 \mathrm{~m}) \mathrm{s}$ trojdílným domem a dalšími přihrazenými stavbami, které společně formovaly hlavní hospodářskou část $\mathrm{s}$ obytnou budovou (obr. 2). V interpretaci dílčích staveb dvora zatím nelze pokročit, nebot' výzkum byl dosud striktně nedestruktivní. U Rychvaldu je třeba vzpomenout i dalších objektů rozptýlených severně od ohrazeného areálu; osovou orientací jsou tyto stavby s dvorem souhlasné a snad tedy vzájemně soudobé. Vzniká tak dojem malé osady. Nejzajímavější 


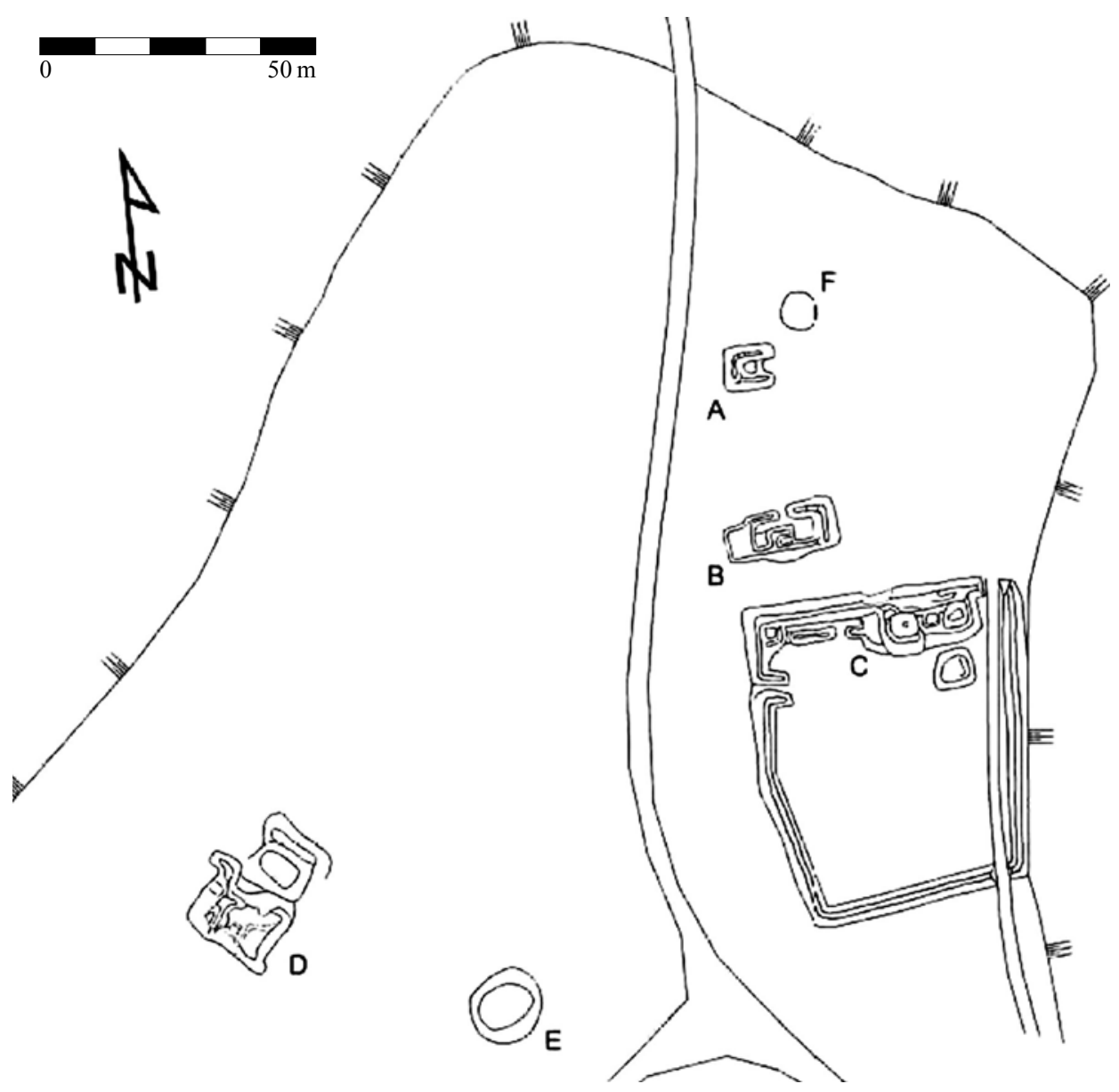

Obr. 2. Rychvald (Kozojedy). Plán dvora a okolních objektů. A, B - zbytky staveb; C - areál dvora s trojdílným domem; D - zděná stavba s ohrazeným dvorkem (sídlo/sýpka?); E - konvexní objekt neznámého účelu; F - cisterna/hnojiště. Upraveno podle Kypta a kol. 2012, 554.

Abb. 2. Rychvald (Kozojedy). Planskizze des Hofes und der umliegenden Objekte. A, B - Gebäudereste; C-Areal des Hofes mit dreiteiligem Haus; D - Steinbau mit eingefriedetem Hof (Sitz/Speicher?); E - konvexes Objekt unbekannten Zwecks; F-Zisterne/Mistgrube. Bearbeitet nach Kypta a kol. 2012, 554.

pozorování ale nabízí výrazná kupa nacházející se 80 m západně od dvora, která byla minimálně patrovou zděnou stavbou o rozměrech ca $12 \times 8 \mathrm{~m}$ a ke které se zřetelně připojuje ohrazený dvorek (ca $14 \times 14$ m; alternativně pozůstatek spalného dílu stavby). Bez odkryvu nebo alespoň geofyzikální prospekce samozřejmě nelze odhadovat, zda se v okolí stavby nachází podobný př́kop jako v př́ípadě Hrnčířu. Domyslíme-li si postupně rozebraný stavební materiál patrové stavby v Hrnčírích, který kdysi musel být podobnou homogenní „kupou“, formální podoba obou areálů je více než zjevná. Je třeba se ptát, jestli není v historických pramenech doložený pojem municio v prŕípadě Rychvaldu na evidovanou patrovou stavbu použit záměrně ve svém užším významu. Těžko soudit, kde by jinak byl sezením Radim, cliens z Lichtenwaldu, připomínaný k roku 1379 (Kypta a kol. 2012, 565-566). Je nepravděpodobné, že by to bylo v běžném trojdílném domě ve dvoře. Můžeme tedy hledět na sídlo, ze kterého byl dvůr spravován a kde byly sekundárně 
uskladněny získávané produkty. V př́ípadě diskutované budovy ale bohužel nelze ani odhadovat časovou souvztažnost ke čtvercové ohradě dvora. Sporý keramický materiál byl sbírán jinde a nedosahuje citlivosti nutné k zachycení podobných přesunů jako u Hrnčířủ a Bedřichova Světce. Ve hře jsou proto i zcela odlišné varianty vývoje celého komplexu. Autoři historické rešerše a průzkumu bez ohledu na tyto skutečnosti přinášejí př́močarou interpretaci, kdy o stavbě mluví čistě jako o sýpce a ostatní varianty spíše vylučují. Další sýpku přitom kladou do prostoru dvora. Vzdálenost věžovité budovy od dvora zdůvodňují oddělením odváděné klášterní renty od spotřebních zásob, v návaznosti na Medunovy interpretace dvora Hrnčíře. Samozřejmě jde o lákavou úvahu a bezdůvodné není ani srovnání s domnělou sýpkou v relativně blízké zaniklé vesnici Svídna. Avšak jde částečně o argumentaci v kruhu, protože ani ve Svídně není stavba interpretována jednoznačně.

Údajná sýpka ve Svídně (Drnek; okr. Kladno) severní stěnou přiléhá k návsi, do jejíž fronty je oproti ostatním usedlostem zřetelně vysunuta, a tvoři jasnou dominantu v čele obce (obr. 3). Samozřejmě je možné připustit, že šlo o objekt sýpky, jak navrhují rychvaldští badatelé. Autory citovanou Smetánkovu zmínku o „bytelné sýpce“ se však nepodařilo zpětně ověřit. Smetánka o stavbě hovoří jako o „dvoře s věži“ a považuje areál za režijní dvưr (Smetánka 1988, 38-39). Stejně dobře by se mohlo jednat o pozůstatek věžovité, cíleně reprezentativní stavby, která byla součástí sídla místního nápravníka či rychtáře. Taková interpretace je lákavá, zvláště

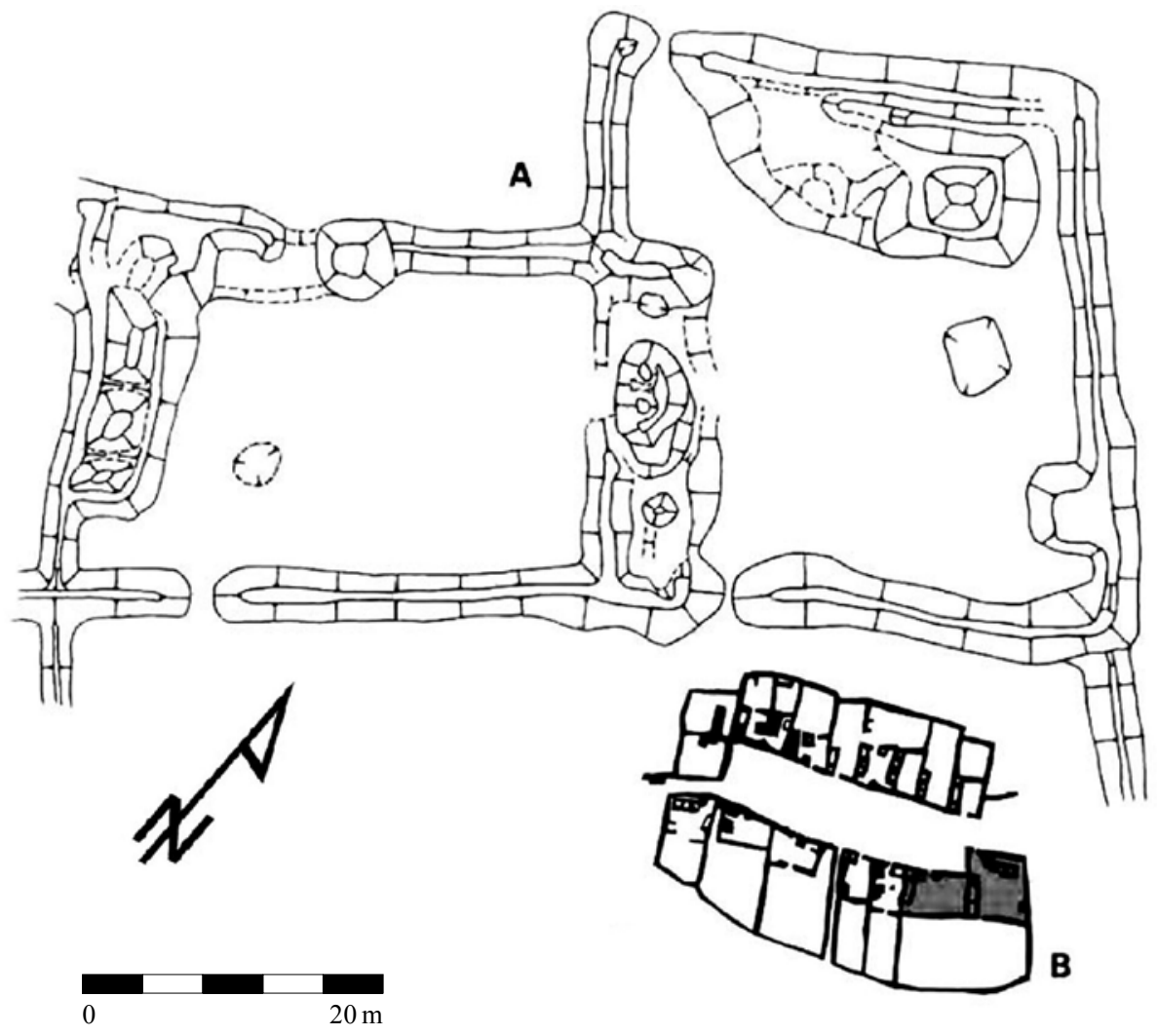

Obr. 3. Dvůr Svídna (Drnek). A - detail reliktů zástavby s věžovitou stavbou v severovýchodním rohu; B - plán ZSV Svídna se zvýrazněním dvora. Upraveno podle Kypta a kol. 2012, 558.

Abb. 3. Hof Svídna (Drnek). A - Detail von Bebauungsrelikten mit turmartigem Bau in der Nordostecke; B - Planskizze der Dorfwüstung Svídna mit hervorgehobenem Hof. Bearbeitet nach Kypta a kol. $2012,558$. 
když Kyptův tým uvádí: „Trosky druhé budovy dvora ve Svídně, které přitahuji naši pozornost, lze v rámci celé vsi označit za nejmohutnější. “ To odpovídá skutečnému terénnímu pozorování. V této části vsi neproběhl odkryv jinde realizovaný v letech 1966-1973, a neznáme proto vybavení popisované věžovité dvoupodlažní stavby (ca $7 \times 7 \mathrm{~m})$, vedle níž se opět nachází plošina, snad přiléhající spalná stavba (Smetánka 1988, 38-39; Kypta a kol. 2012, 560-561). Určitou představu předestírá např́íklad vybavení manských dvorů v Libici nad Cidlinou, které byly rovněž součástí parcelace obce a kde je doložena sekvence kvalitních kachlových kamen, skleněné okenní výplně i nádoby či loštická keramika. Charakter zástavby libických dvorů je ale bohužel nejasný (Justová 1985, 258-260; Princová-Justová 2000; 2002).

Alternativní interpretace zmíněných věžovitých kamenných objektů se zakládá na dalších nových př́ikladech, mezi které se řadí lokalita Kozinec na katastrálním území Berouna. ${ }^{4}$ Tam byl roku 2012 ve spolupráci s P. Vařekou geodeticky dokumentován areál ohrazeného sídla/dvora v nevýrazné poloze při hraně široké ostrožny (obr. 4). ${ }^{5}$ Zdivem ohrazený prostor $(50 \times 38 \mathrm{~m})$ zahrnoval kamennou, patrně obytnou stavbu o dvou dílech $(23 \times 10 \mathrm{~m}$; věžovitý díl ca $11 \times 10 \mathrm{~m}$; výška destrukčního kužele až $2 \mathrm{~m}$ ), do které se vstupovalo ze sníženého dvorku. Dále pozorujeme kamennou podezdívku (hospodářské?) budovy $(18 \times 8 \mathrm{~m}) \mathrm{s}$ vedle položenou cisternou/studní. V prostoru ohrazení nelze vyloučit další spalné stavby, které nebyly povrchově zaznamenány. Ohrazení bylo ve východní části prolomeno jednoduchou branou, na kterou navazovala cesta směřující po vrstevnici $\mathrm{k}$ východu. $\mathrm{V}$ okolí nebyly registrovány další objekty ani pozůstatky plužiny. Povrchové nálezy redukčně pálené keramiky areál řadí do druhé poloviny 14. a počátku 15. století a sběrem z narušení byly získány zlomek nože a podkova. Poloha dvora a absentující plužina naznačují jiné než primárně hospodářské využití areálu, přičemž terénní situace je velmi podobná zaniklému Rychvaldu, kde plužina rovněž není evidována. Celkové znaky jsou spíše shodné s předešlými lokalitami a rýsuje se před námi zajímavá kategorie osamocených, ohrazených nebo lehce opevněných dvorů, které nemají přímou vazbu na vesnické osídlení a obsahují zástavbu i nálezy indikující vyšší sociální vrstvy. Hlavním znakem se stává přítomnost věžovité stavby. Přípustná je i interpretace poslední zmíněné lokality jako manského domu, snad čistě rezidenčního objektu. Podobný areál byl starší literaturou v náznacích evidován v poloze Dubina (původní název Skalka) nedaleko Křivoklátu. Na Skalce byl sběrem T. Durdíka získán soubor kachlů a prejzů (Novák-Vařeka 2015, 520). Přesný charakter sídla ale v tomto případě nelze na základě dostupných pramenů posoudit. Samotná existence a poloha objektu je velmi nejistá. ${ }^{6}$

Dalším modelovým př́íkladem při hodnocení lokalit na pomezí sídla a solitérního dvora je poloha zvaná Staré Zámky poblíž Libušína (okr. Kladno), ${ }^{7}$ ležící na okraji plošiny, jejíž svahy prudce spadají do hluboce zařízlých údolí. I zde byl realizován nedestruktivní výzkum, který prokázal výjimečně kvalitně zachované pozůstatky sídla s věžovitou stavbou, o celkových rozměrech $41 \times$ ca $66 \mathrm{~m}$ (obr. 5). Na severní a východní straně je lokalita vymezena hranou svahů a na západní straně torzem mělkého př́ikopu (šířka $3,5 \mathrm{~m}$; hloubka $0,5 \mathrm{~m}$ ) o délce $22 \mathrm{~m}$, který na vnitřní straně lemuje destrukce kamenné ohradní zdi. Stopy hrazení postrádáme na jižní straně. Na severní straně se nachází umělý pahorek dosahující výšky $1-1,5 \mathrm{~m}$, na jehož vrcholové plošině je patrná podezdívka věžovité stavby dřevěné konstrukce o rozměrech $6,5 \times 6,5 \mathrm{~m}$. Směrem do dvora se při patě pahorku nachází plochý stupeň, na kterém mohlo být umístěno ohrazení. Na východní straně přiléhalo k pahorku obytné stavení $(11 \times 14 \mathrm{~m})$ s pozůstatky pece, které bylo dřevěné, na kamenné podezdívce a členěné do tř́i dílů. Podél východní hrany plošiny se nachází objekty, které mohly sloužit hospodářským účelům, ovšem není jasné, zda šlo o celé křídlo, či o samostatné, stavebně neprovázané budovy. Výrazný konvexní objekt může představovat kamenný špýchar, větší konkávní útvar zřejmě indikuje suterén a plošina další dřevěnou část zástavby. S lokalitou nedokážeme spojit žádné zmínky psaných pramenů, a proto jedinou oporou

\footnotetext{
4 Do literatury ji uvedl A. Sedláček (1882-1927, VI: 92) a stručně na ni upozornil J. Synek (1998).

$5 \mathrm{Za} \mathrm{pomoc} \mathrm{se} \mathrm{zaměřením} \mathrm{lokality} \mathrm{děkuji} \mathrm{M.} \mathrm{Peštovi.}$

6 Nálezy se mohly v dané poloze vyskytovat druhotně.

7 První zmínku zde předestírá F. A. Heber $(2012,262)$, lokalita se objevuje v Soupisu památek (Velc 1904, 105-106) a později se stává rejdištěm detektorářů a předmětem nesystematických sběrů (Durdík-Krucký 2003).
} 


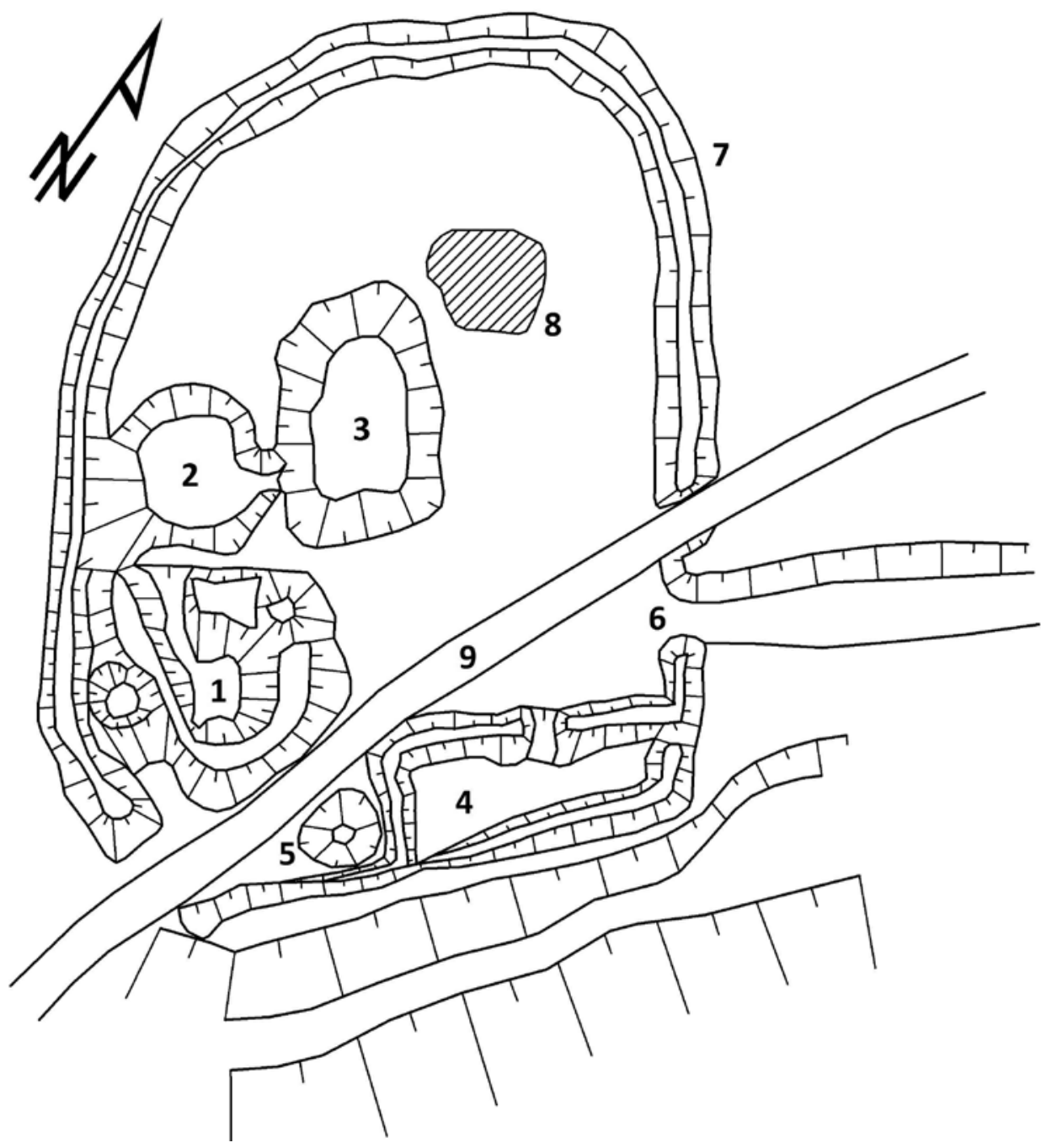

Obr. 4. Dvůr Kozinec (Beroun). 1 - zděný díl hlavní budovy; 2 - vstupní díl hlavní budovy tvořený lehčí konstrukcí; 3 -zahloubený prostor dvorku se vstupem do hlavní budovy; 4 - hospodářská budova (stáje/chlév?); 5 - cisterna/studna; 6 - původní vstup s navazující komunikací; 7 - zděné ohrazení; 8 - neinterpretovaný konvexní objekt; 9 - recentní cesta prolamující ohrazení na obou stranách. Zaměření a plán D. Novák, P. Vařeka a M. Pešta.

Abb. 4. Hof Kozinec (Beroun). 1 - Steinteil des Hauptgebäudes; 2 - von leichterer Bauweise gebildeter Eingangsteil des Hauptgebäudes; 3 - eingetiefter Hofraum mit Eingang zum Hauptgebäude; 4 - Wirtschaftsgebäude (Stall?); 5 - Zisterne/ Brunnen; 6 - ursprünglicher Eingang mit anschließendem Verkehrsweg; 7 - Steineinfriedung; 8 - nicht interpretiertes konvexes Objekt; 9 - die Einfriedung auf beiden Seiten durchbrechender rezenter Weg. Vermessung und Planskizze D. Novák, P. Vařeka und M. Pešta. 
0

$40 \mathrm{~m}$

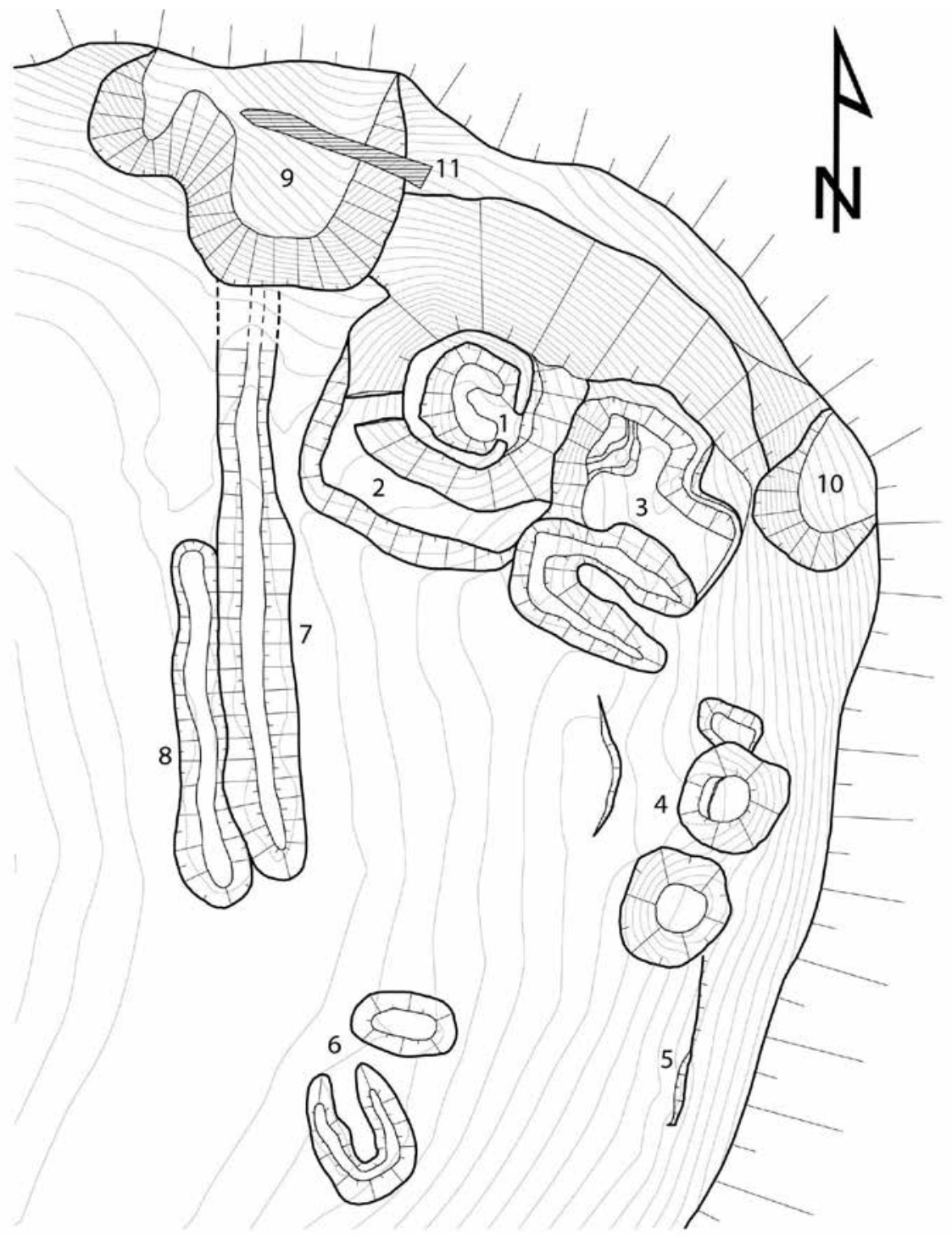

Obr. 5. Dvůr Staré Zámky (Libušín). 1 - umělý pahorek s relikty věžové stavby; 2 - terénní stupeň; 3 - zřejmě hlavní obytné stavení; 4 - objekty indikující pravděpodobně hospodářské stavby; 5 - relikt podezdívky; 6 - objekty neznámé funkce; 7 val; 8 - příkop; 9 - lomy/sesuvy půdy; 10 - recentní narušení. Zaměření a plán D. Novák a P. Vařeka.

Abb. 5. Hof Staré Zámky (Libušín). 1 - künstlicher Hügel mit Relikten eines turmartigen Baues; 2 - Geländestufe; 3 - offenbar Hauptwohngebäude; 4 - wahrscheinlich Wirtschaftsgebäude indizierende Objekte; 5 - Relikt einer Grundmauer; 6 - Objekte unbekannter Funktion; 7 - Wall; 8 - Graben; 9 - Erdbrüche/-rutsche; 10 - rezente Störung. Vermessung und Planskizze D. Novák und P. Vařeka. 


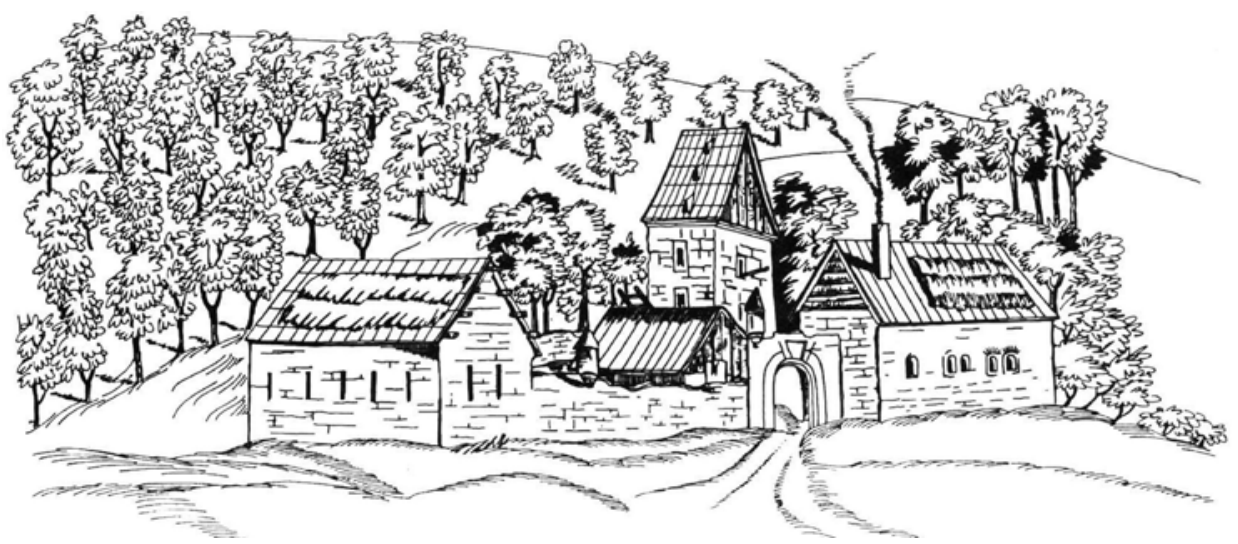

Obr. 6. Dvůr Kouskova Lhota podle vyobrazení na vedutě ze Zeleného pokoje zámku v Týnci. Upraveno podle Anderle a kol. 1989, 341 .

Abb. 6. Hof Kouskova Lhota gemäß der Darstellung auf einer Vedute aus dem Grünen Zimmer des Schlosses in Týnec. Bearbeitet nach Anderle a kol. 1989, 341.

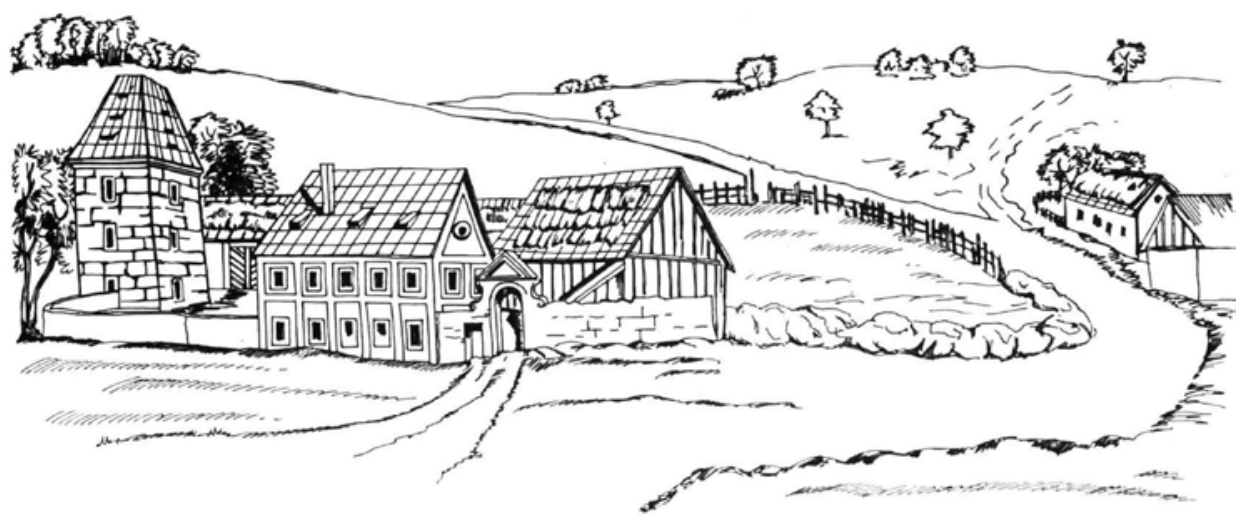

Obr. 7. Dvůr Vrhaveč podle vyobrazení na vedutě ze Zeleného pokoje zámku v Týnci. Upraveno podle Anderle a kol. 1989, 340.

Abb. 7. Hof Vrhaveč gemäß der Darstellung auf einer Vedute aus dem Grünen Zimmer des Schlosses in Týnec. Bearbeitet nach Anderle a kol. 1989, 340.

datování jsou archeologické nálezy. Sběry realizované T. Durdíkem a M. Kruckým poskytly malý soubor keramiky ze 14.-15. století a další získané artefakty zahrnují dva nože (jeden kus představuje jídelní nůž vysoké kvality zdobený barevnými kovy), klíč, podkovu a další železné artefakty. V př́ípadě Starých Zámků se setkáváme s podobným konceptem jako u minulých lokalit, nicméně forma věžovité stavby se tentokrát liší lehčí konstrukcí a polohou na nízkém umělém pahorku. Budovy zůstávají velmi skromné, i přes uvedené movité nálezy značící vyšší sociální prostředí.

Na tomto místě vzpomeňme známou Biblia Wenceslai Regis a v ní obsažené vyobrazení dvora (Novák 2016, 132-133). Formální znaky dvora na vyobrazení jsou velmi instruktivní při modelové rekonstrukci areálu torzálně zachyceného ve Starých Zámcích, zejména díky přítomnosti lehkého ohrazení a výrazné, ze dřeva vystavěné věže s přiléhající př́izemní stavbou. Vedle tohoto vyobrazení můžeme pro názornost položit veduty Kouskovy Lhoty a Vrhavče (obr. 6 a 7), které zachycují kamenné varianty formálně velmi podobných sídel/dvorů. V torzálně zachovalé 


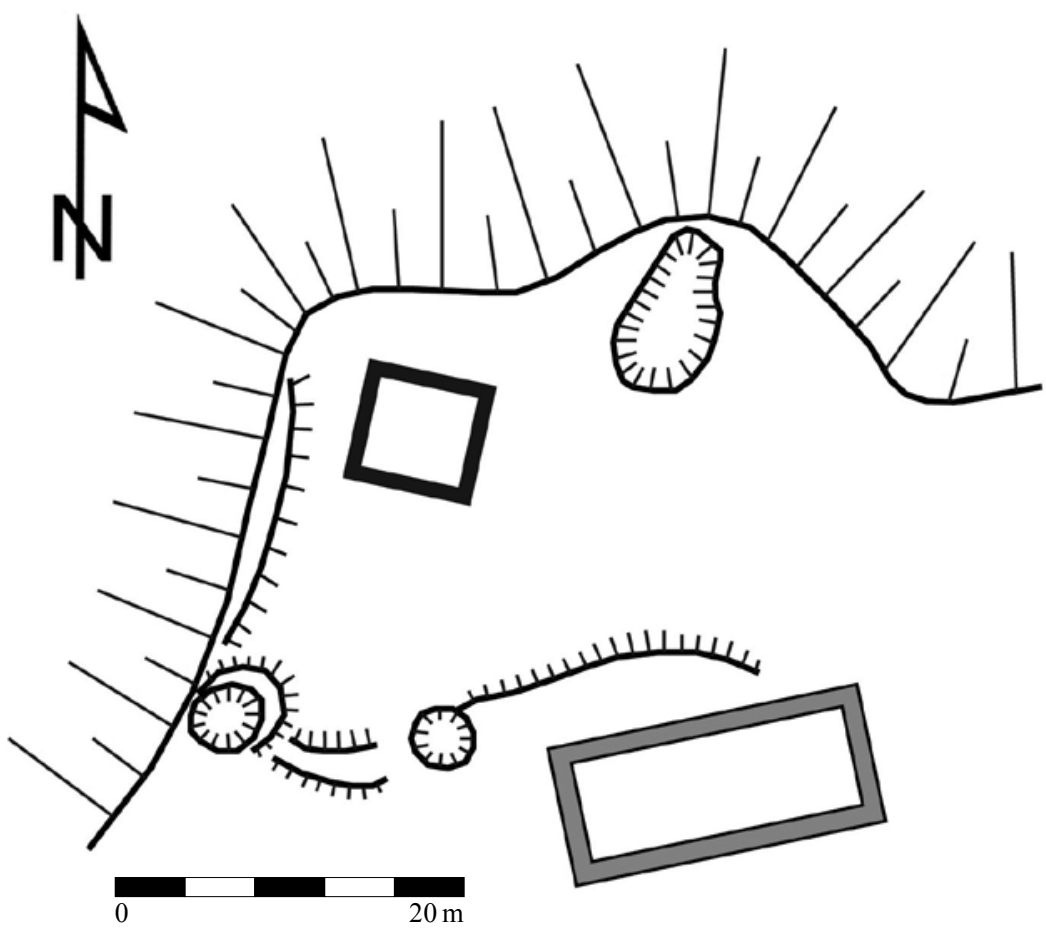

Obr. 8. Dvůr Lina (Vrbička) s téměř čtvercovou, nehrazenou věžovou stavbou. Upraveno podle Kolektiv 1998-2005, 406. Abb. 8. Hof Lina (Vrbička) mit einem fast quadratigen, nicht eingefriedetem Turmbau. Bearbeitet nach Kolektiv 1998$2005,406$.

podobě můžeme snad podobnou variantu dvora s jednoduchým sídlem spatřovat na lokalitě Lina (Vrbička; Durdík 1997; obr. 8), kde je pečlivě zbudovaná věž o rozměrech ca $8 \times 7 \mathrm{~m}$ dochována jako ruina do výše př́izemí v neopevněném areálu a ve strategicky nevýhodné poloze.

Historický popis zaniklého dvora v Hodkovičkách u Prahy ${ }^{8}$ přináší též jisté indicie - jmenována je „uprostřed kamenná věž, v niž je malá jizba s dřevěnou podlahou“. I přes zrádnost písemných pramenů je zde věž popisována jako obytná, či jinak sídelně využitá stavba (pojem stubella), nikoli jako sýpka. Následující budova, ,kamenný dům šafářưv u hlavních vrat dvora s príslušnou jizbou", také působí při znalosti archeologických situací Svídny, Rychvaldu i Hrnčířů povědomě. Skladovací prostory jsou přitom zmíněny odděleně: „dvě kamenné sýpky kryté šindelem nebo došky“; podobné stavby identifikujeme např́iklad na lokalitě Rovný (Drahoňův Újezd; Novák-Vařeka 2016), kde shledáváme dvojici menších špýcharů (jeden do patra kamenný, druhý na kamenné podezdívce; obr. 9: obj. 24, 81). Podobný kupovitý útvar, snad špýchar, nalézáme i ve Starých Zámcích (obr. 5: obj. 4).

8 „Primo videlicet curia bene muro circumdata, turris lapidea in medio curie sita in qua erat parva stubella cum pavimentis suis competentibus de ligno constructis, it domus coloni prope portam maiorem lapidea cum stuba competenti, it. celarius parvum, it. duo magna stabula et tria parva omnia lapidea pro pecoribus, pecudibus et equis ac eciam aliis animalibus, it. duo horrea lapidea cum glossis seu straminibus cooperta“ (Graus 1957, 67). V překladu: „Dvůr obehnaný zdí, uprostřed kamenná věž, v níž je malá jizba s dřevěnou podlahou, kamenný dům šafár̆ùv u hlavnich vrat dvora s príslušnou jizbou, malý sklep, dvě velké stáje a tři malé, vše z kamene, pro dobytek, koně a ostatní zvírata, dvě kamenné sýpky kryté šindelem nebo došky“ (Chotěbor-Smetánka 1985, 53). Je zajímavé, že popis nezmiňuje vodní opevnění, které patrně tvořil rybník obíhající dvůr přinejmenším ze třech stran, jak vyplývá ještě z mapy Stabilního katastru. 


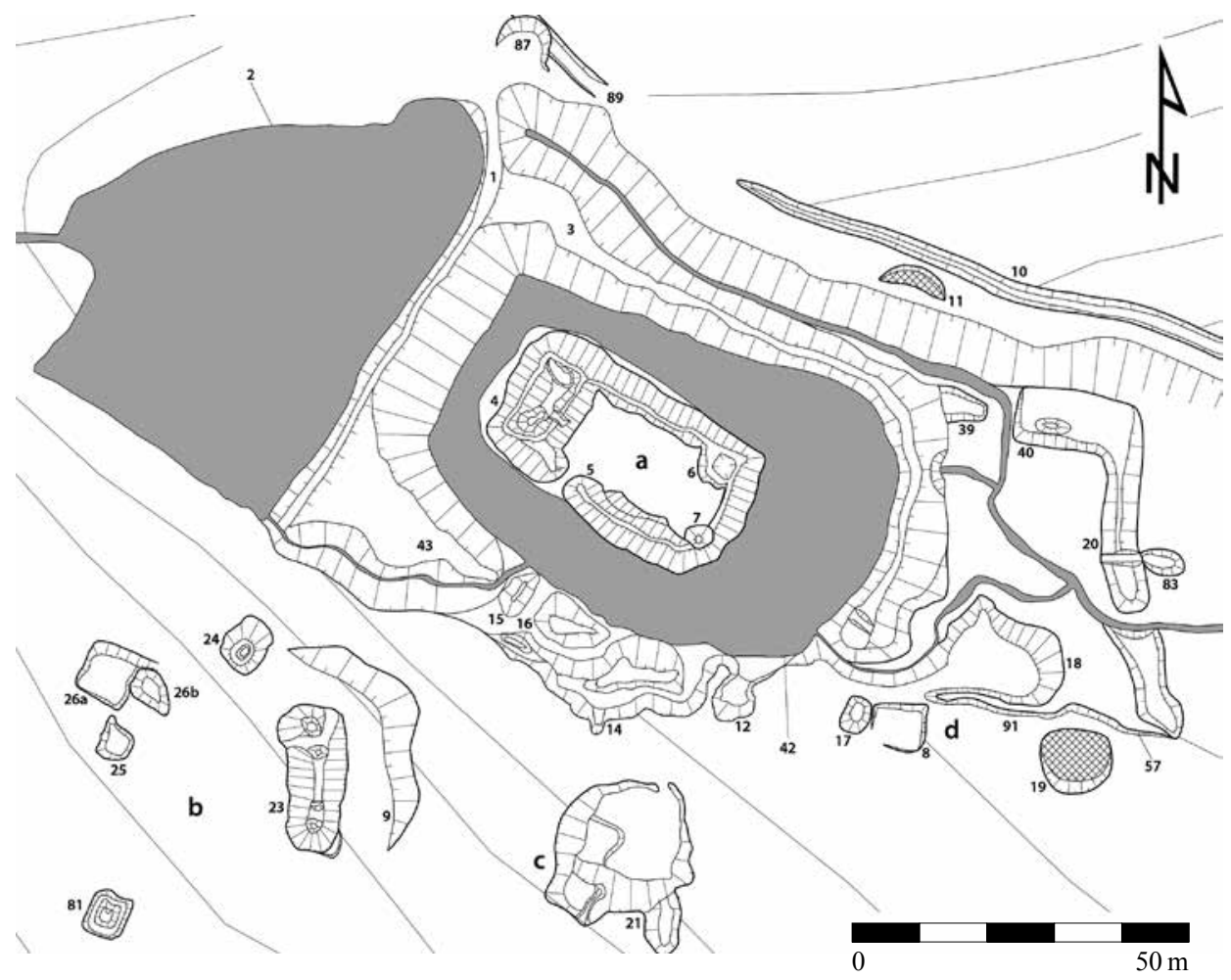

Obr. 9. Tvrz a dvůr Rovný (Drahoňův Újezd). a - opevněné sídlo; b - dvůr; c-lom; d - předpokládaný mlýn. Plán P. Vařeka. Abb. 9. Feste und Hof Rovný (Drahoňův Újezd). a - befestigter Sitz; b - Hof; c - Bruch; d - mutmaßliche Mühle. Planskizze P. Vařeka.

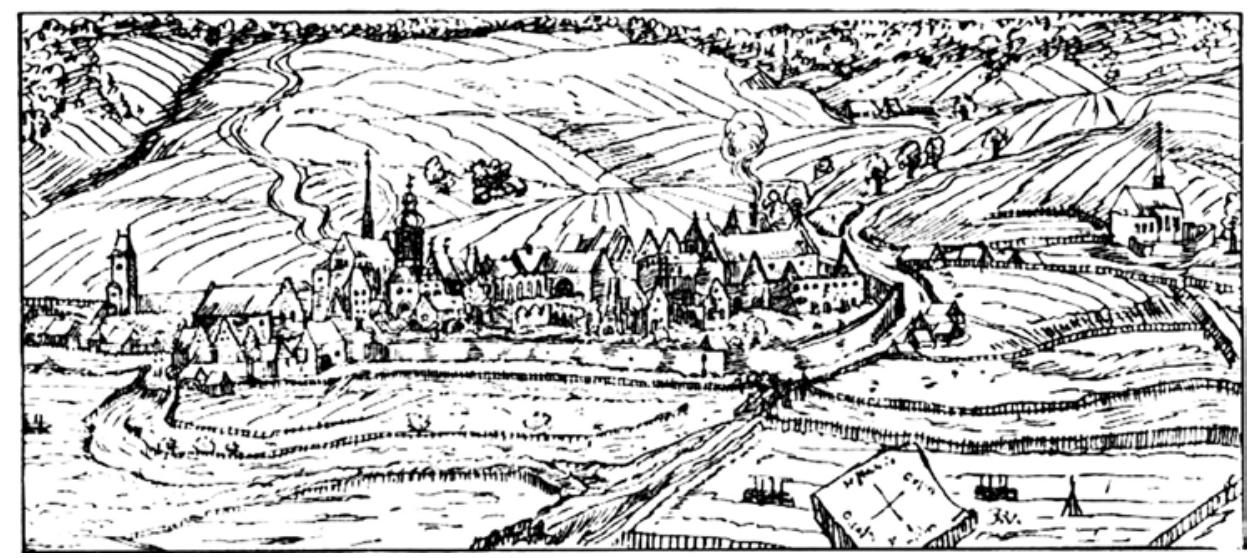

Obr. 10. Willenbergova veduta kláštera Plasy z roku 1602. Dnes torzálně dochovaná gotická věž v klášterním dvoře je viditelná v levé části veduty. Zdroj http://www.plasy.cz/turista/galerie/fotografie/nkp-klaster-plasy/.

Abb. 10. Kloster Plaß auf einer Vedute von Willenberg aus dem Jahr 1602. Der heute als Torso erhaltene gotische Turm im Klosterhof ist im linken Teil der Vedute zu sehen. Quelle http://www.plasy.cz/turista/galerie/fotografie/nkp-klaster-plasy/. 


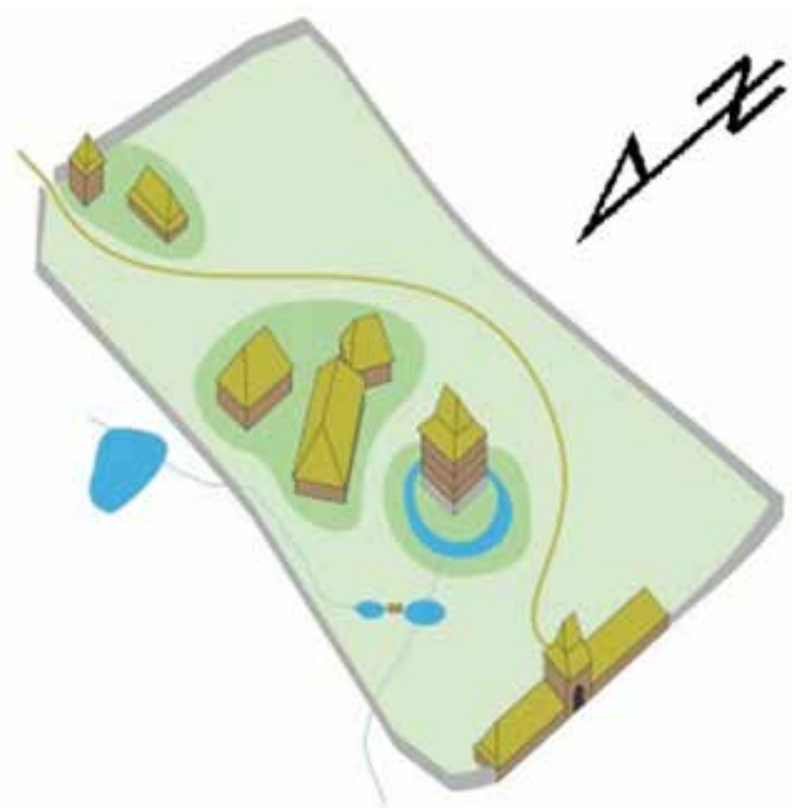

Obr. 11. Dvůr Džbánek (Jarov) se samostatně ohrazenou věží. Upraveno podle J. Sankota. Zdroj http://www.chvalenice.cz/ obec-107/z-historie-obce-1/kapitoly-z-historie/zajimava-mista-v-okoli/stredoveka-tvrz-a-vsi-pod-farskou-skalou/.

Abb. 11. Hof Džbánek (Jarov) mit eigens eingefriedetem Turm. Bearbeitet nach J. Sankota. Quelle http://www. chvalenice.cz/obec-107/z-historie-obce-1/kapitoly-z-historie/zajimava-mista-v-okoli/stredoveka-tvrz-a-vsi-pod-farskou-skalou/.

Vzpomeňme i na slovenské Zalužany, kde je podoba a obytná funkce věžovité stavby $(10 \times$ $9 \mathrm{~m}$ ) při obvodu dvora ze 13. století jednoznačná. Stavba věže se zachovala opět v areálu ohrazeném prostou zdí, který mimo jiné obsahoval i hospodářské budovy a kovárnu. Vývoj jádra byl, stejně jako jinde, založen na postupné proměně zástavby narůstáním a zanikáním dílčích částí (Polla 1962, 42-88). Jako zajímavý příklad poslouží i Dolný Poltár, kde byla výzkumem zachycena neopevněná obytná věž opatřená hospodářským zázemím s doloženou výrobou keramiky pro tržní účely, datovaná do 13. století (Hrubec 1971). Z analogií přidejme oba známé dvorce v Trocnově, kde jde o velmi skromné varianty sídel tvořené pouze přízemními budovami (Kolektiv 1998-2005, 859-860). Nelze najít mnoho znaků, kterými se takové lokality fundamentálně odlišují od ostatních výše jmenovaných dvorů/sídel. V př́padě Trocnova jde dokonce o kvalitativně méně vyvinuté objekty, které patrně neměly věžovitý charakter. Nejasným argumentem v diskusi je př́iklad známé, téměř zaniklé věžové stavby na klášterním dvoře v Plasích, která v dané souvislosti mohla sloužit čistě utilitárně (obr. 10). Nevíme ale, kde ležel Vladislavův dvorec zmiňovaný při zakládací donaci kláštera (Rožmberský 2008, 4) a jaký vztah měl k nové grangii. Věž mohla sloužit ještě ve 14. století jako sídlo svobodného nápravníka, který byl klášterním beneficiářem. Taková sídla předpokládáme ve dvorech Džbánek (Nebílovský Borek; obr. 11) a Třebekov (Jarov) nacházejících se rovněž na Plzeňsku a kladených do souvislosti s plaským klášterem. $V$ těchto př́ípadech již věžovitá stavba nabývá podoby srovnatelné s plnohodnotnými věžovitými tvrzemi své doby, nicméně stále se nacházela $\mathrm{v}$ rámci hrazeného areálu dvora, ze kterého byla vydělena pomocí nevýrazných př́kopů a zdí na pomezí ohrazení a opevnění (Anderle-Rožmberský-Švábek 1993). 


\section{Za hranicí sídel vrchnosti}

Do výčtu zkoumaných lokalit bychom mohli zařadit i další, které svými parametry na první pohled z popisované skupiny nevybočují. Namátkou se nabízí například zaniklé pozdně středověké dvory Olešná (okr. Rokycany; Vařeka 2014a) a Nevězeň (Mlečice; okr. Rokycany; Vařeka 2008), oba rámcově řazené do 14.-15. století. V obou prŕípadech jde o areály, u kterých bychom jako hlavní rozdíl oproti rolnickému gruntu mohli jmenovat osamocené umístění. Stejně jako v řadě předchozích případů (Rychvald, Kozinec, Staré Zámky, Lina) je jejich poloha hospodářsky nevýhodná - oba areály leží na úbočí svahů (periferie extravilánu okolních vesnic?), i když v okolí obou lokalit tentokrát na snímcích leteckého laserového skenování identifikujeme pozůstatky mezních pásů zaniklé plužiny. Zástavba je v obou př́ípadech nevýrazná, snad z větší části dřevěná a ohrazení není evidováno vůbec. Na obou lokalitách naopak vidíme pozůstatky drobných vodních nádrží, snad napajedel pro dobytek. Písemné prameny oba dvory zmiňují jen nepř́mo.

Podobné dvory jsou díky intenzivní prospekci odhalovány i v dalších částech Čech (Bolešov na Chrudimsku: Musil-Netolický 2016, 214-218; tzv. dvořácké samoty na Havlíčkobrodsku: Rous 2010; 2011). K podobné kategorii mohly náležet i oba doložené dvory v zaniklé vsi Kokot (Bušovice; jeden dvůr není interpretován jednoznačně), z nichž větší snad nahradil starší věžovitou tvrz položenou na návsi. Do výbavy tohoto dvora patřila kachlová kamna, ovšem stopy po věžovité stavbě v jeho rámci neevidujeme. Jde však o dvůr vzniklý až počátkem 15 . století, tedy mladší než uvedené prř́klady (Buračinská 2008) a může tak odrážet i nástup jiných sídelních forem typických pro pozdější pozdně středověké a raně novověké období, kdy věžovité objekty postupně ztrácejí své výsadní postavení při definici elitních sídel. Není ani zcela jasný jeho chronologický vztah k původní tvrzi uprostřed návsi - oba areály mohly být zčásti současné.

Starším odrazem osamocených dvorů teoreticky mohou být lokality jako Poněšice (okr. České Budějovice; Břicháček 1993) nebo Ledčice (okr. Mělník; Gojda a kol. 2010), datované do sklonku 12. a první poloviny 13. století. V prvním případě se na palisádou ohrazeném jednodílném dvorci (ca $35 \times 50 \mathrm{~m})$ nacházela kůlová stavba $(6,4 \times 4,8 \mathrm{~m})$ doplněná o další zahloubený objekt (zemnici; $3 \times 3 \mathrm{~m})$, blíže nespecifikovanou dřevěnou budovu $(3 \times 4 \mathrm{~m})$ a železářskou pec. Rozsáhlý ledčický areál naproti tomu tvořily tři $\mathrm{k}$ sobě přiložené díly vymezené př́ikopy (obr. 12). V jádru hlavního obdélného ohrazení se zaoblenými rohy $(60 \times 40 \mathrm{~m})$ se nacházela dvojice zahloubených objektů s kůlovou konstrukcí - snad pozůstatek větší stavby, která byla odhalena jen v náznacích. Navazující čtvercový díl $(45 \times 45 \mathrm{~m})$ se otvíral přerušením k západu a obsahoval sporadické stopy kůlových staveb. Třetí díl (ca $115 \times 105 \mathrm{~m})$ tvořil rozsáhlou ohradu obtáčející celý dvorec směrem od východu. Interpretace tohoto typu dvorců není jasná, ale v kontextu dalších nalézaných lokalit (včetně prvního a druhého horizontu Hrnčíruũ) se snad jedná o předchůdce panských a církevních hospodářských dvorů budovaných bez významnějšího zastoupení rezidenční funkce v otevřené krajině. Velké ohrady - jako ta tvořící východní díl Ledčic nebo obdobná identifikovaná ve Velebudicích (okr. Most; Klápště 1994, 80-83, 149) mohou naznačovat využití dvorců pro chov dobytka (Gojda a kol. 2010, 288). Do podobné kategorie spadá i raná fáze Hrnčířů, odkud ale pochází zmíněné nálezy značící přítomnost vyšších sociálních vrstev (šipky a ostruha), čímž se jednoznačná interpretace komplikuje, i když mohlo jít o intruze nebo pozůstatky specifické události bez vazby k provozu dvora.

Co je pro všechny tyto areály společné, je absence věžovitých staveb v podobě zachycené předchozí kapitolou. Žádný z uvedených dvorů či dvorců tak nenaznačuje, že by zde docházelo k vybudování stavby, která by evokovala elitní prostředí ve smyslu věžovitých sídel, která byla budována např́č krajinou. I přestože ostatní výbava těchto dvorů byla velmi podobná předchozím prŕípadům, je relevantní otázkou, zda právě toto není úroveň, kde hledat první „velkostatky“ a svobodnické dvory, které nespadají do mozaiky vrchnostenských sídel a od poddanské usedlosti se liší pouze vybavením, nikoli svou stavební podobou. Jejich obyvatelé nebyli vrchností 


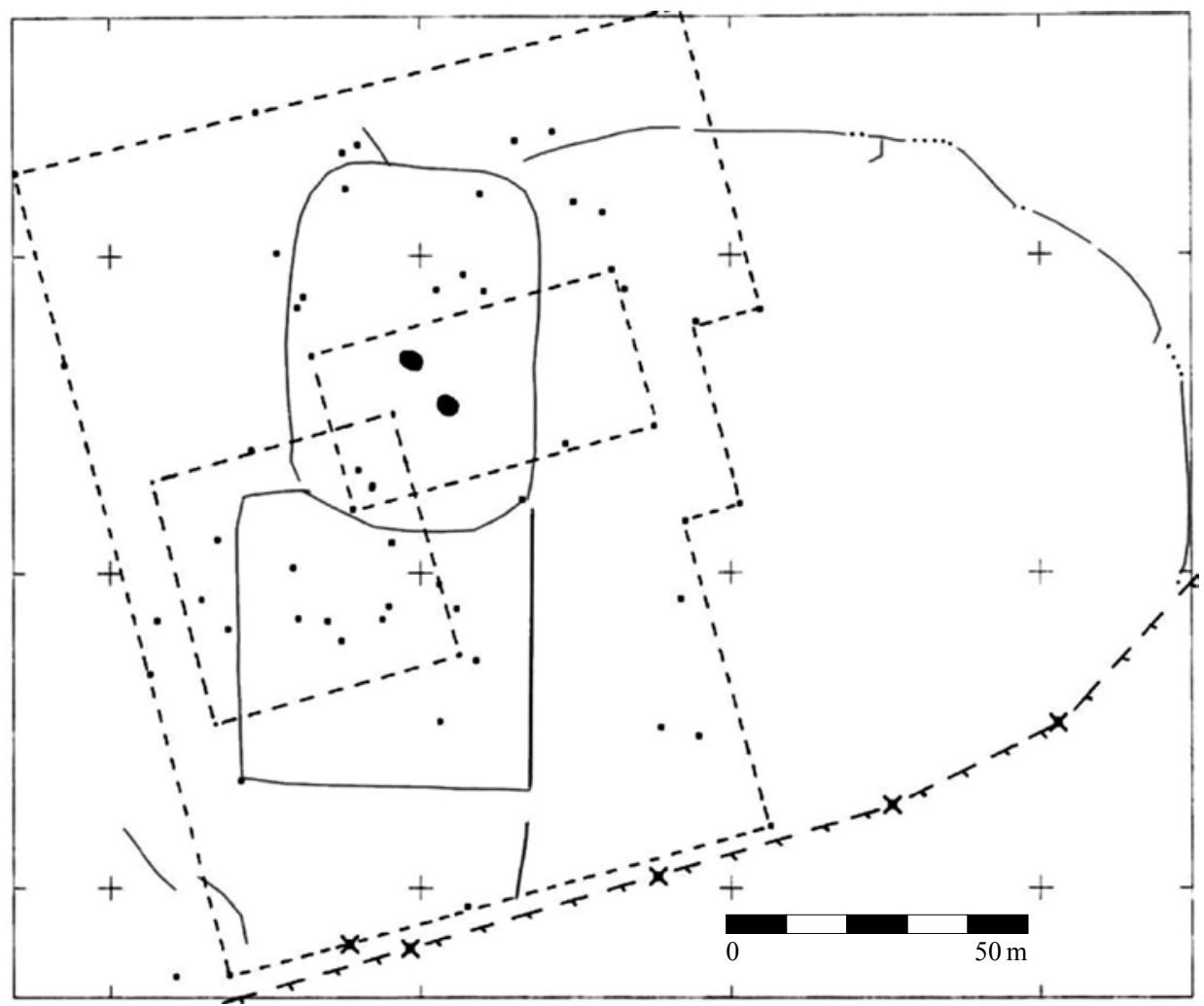

Obr. 12. Dvorec Leděice. Plnou čarou schematicky vyznačen průběh ohrazení. Upraveno podle Gojda a kol. $2010,272$. Abb. 12. Herrenhof Ledčice. Der Verlauf der Einfriedung wird mit schwarzer Linie schematisch gekennzeichnet. Bearbeitet nach Gojda a kol. 2010, 272.

ani na úrovni klientského či lenního vztahu. Takové dvory často mohly sloužit čistě jako hospodářské produkční jednotky, což ostatně naznačují indicie o jejich roli v dobytkářství (nádrže, ohrady).

\section{Sýpka, sídlo nebo symbol vrchnosti?}

Přestože výklad věžovitých staveb situovaných uvnitř (nebo poblíž) zástavby dvorů není jednoznačný, je možné shodnout se na podobných formálních znacích popsaných objektů. Ač odkryvy některých lokalit a jejich artefaktuální výbava dávají zřetelné náznaky o interpretaci, stále nevylučujme, že u těchto areálů hospodářská funkce převažovala a architektonické ztvárnění hlavní budovy mělo čistě symbolickou hodnotu. Při označení uvedených staveb jen jako špýcharů / sýpek ${ }^{9}$ bychom však neměli ignorovat nejen jejich zjevně nejvýstavnější podobu v rámci uvedených areálů, ale také dosavadní znalosti o podobě věžovitých špýcharů, at' už jsou

9 Oba pojmy označují funkčně stejné stavby. V př́ipadě špýcharu máme obvykle na mysli čtvercový věžovitý objekt, v případe sýpky spíše stavbu na obdélném půdorysu, nebo obecně funkční vymezení části stavby (srov. Vařeka-Frolec 2007, 288, 292). V kterémkoli z případů samozřejmě mohla věžovitá budova spojovat obě funkce - skladovací i obytnou. 
to př́iklady moravské (Nekuda 2008, 100-103), z Plzeňska (Dudková-Orna-Vařeka a kol. 2008, 47-65; Vařeka a kol. 2006; 2008) nebo z Černokostelecka (Smetánka-Klápště 1981). Vždy jde o budovy o maximální rozloze do ca $30 \mathrm{~m}^{2}$ a relativně jednoduché konstrukce, které silně kontrastují se sledovaným typem objektů o zastavěné ploše v rozmezí ca $40-100 \mathrm{~m}^{2}$ - oba intervaly se tak ani neprotínají. Př́ípadná skladovací funkce takových staveb přitom nevylučuje, aby budova sloužila jako obytně-reprezentativní prostor („Trinkstube“; Rykl 2008, 48-49).

J. Varhaník ve svém zhodnocení sporně interpretovaných sýpek na hradech připouští možnou úlohu těchto výstavných budov (podobných palácům) při šlechtické reprezentaci i v nejvyšším sociálním kontextu (Varhaník 2018, 397). Ze zachovalých staveb podobného typu v prostředí středověkých dvorů mimo hradní areály stojí za zmínku rozlehlá raně gotická sýpka dvora v Plasích (Rožmberský 2008, 6-9), pozdně gotická víceúčelová sýpka při dvoře v Tuchorazi (Chotěbor-Smetánka 1985, 53-54) a chronologicky i formálně jí blízká sýpka ve Zvířeticích (Žižka 1999, 23-24). Zajímavým detailem v Tuchorazi i Zvířeticích jsou stopy po pavlačích zpřístupňujících horní patra, což evokuje možnost připodobnění k palácové stavbě sídla. Podobné objekty v sousedství hradních staveb nejsou neobvyklé ani mimo české území. Obsahují kromě skladovacích prostor i ty reprezentativní, které nelze spojovat s ekonomickou funkcí. Ačkoli takové budovy nebyly přímo součástí sídel, byly prostředkem vyjádření prríslušnosti přidruženého areálu k panskému zboží (Kühtreiber 2004).

Dosud nebyla zmíněna též jedna podstatná souvislost několika diskutovaných lokalit, a to poloha při okraji výrazného terénního zlomu na širokých plochých ostrožnách. Týká se to Starých Zámků, Kozince, Rychvaldu, Liny a do jisté míry i Svídny. Umístěním většinou nešlo o polohy vhodné k obraně. Je nasnadě, že budovy, primárně určené k zajištění ekonomických funkcí, by pravděpodobně vyhledávaly méně prominentní polohy, jako je tomu u běžných hospodářských dvorů. Paradoxně ale právě v rovinatějším terénu měla stavba vyšší potenciál ke kontrole okolí (obr. 13), než tomu bylo u objektů umístěných ve zmíněných polohách (obr. 14). ${ }^{10}$ Zejména $\mathrm{v}$ případě Kozince, Liny, ale i Rychvaldu by bylo možné poměrně malým posunem dosáhnout podstatně vyššího vizuálního účinu. Že by tak věžovité objekty ve dvorech byly cíleně budovány jako kontrolní body, lze spíše vyloučit, snad s výjimkou Starých Zámků u Libušína, kde poloha dává dobrý přehled nad celým okolním terénem a více se blíží umístěním typickým pro hrazená sídla.

Podobné stavby jako ty popisované v našem prostředí se podařilo rozeznat i na rakouském území, a to i ve stojících stavbách. Jde o neopevněné věžovité objekty, které mohou být integrované s jinými budovami, ale mohou též stát solitérně. Podle rozboru psaných pramenů jsou často spojovány právě s pojmy curia či curtis. Analýza zahrnující objekty pocházející z širokého rozpětí 13.-18. století odhalila jejich společný charakter, který se zakládal na militárních znacích (řešení vstupů a oken, masivnější zdivo, vnější vzhled budovy), který však nebyl podpořen praktickou obrannou funkcí. Budovány byly tak, aby zdůrazňovaly svou výšku, často s využitím svažitosti terénu. Stavbám je pak sice přikládána skladovací funkce, nicméně jako důležitý je chápán jejich reprezentativní charakter. Rezidenční funkce jako taková se s těmito objekty nespojuje kvůli absenci otopných zařízení a dalších znaků obytné stavby. Vzhledem k odkazům na patrové komorové díly běžných usedlostí identifikované na moravských vesnicích je ale těžké soudit, nakolik je tato skupina staveb vydělena konzistentně a relevantně ve vztahu k hospodáŕským dvorům důvodně spojovaným s vrchnostenským prostředím (Kühtreiber 2014, 42-45). Přesto je zajímavá míra sdílené symboliky takových objektů s vrchnostenskými sídly v pravém slova smyslu.

Díky zhodnocení uvedené množiny lokalit a pramenů se lze s jistou opatrností přiklonit $\mathrm{k}$ interpretaci, že pozorujeme dosud jen v náznacích zachycovanou skupinu objektů koncipovaných jako hospodářské jednotky s reprezentativní věžovitou budovou. Ta mohla mít parciálně i skladovací funkci, která nevylučuje obytně-reprezentativní charakter jiných částí stavby, což dokládají i archeologické nálezy skladovacích prostor s pozůstatky obilovin uvnitř jader sídel

10 Model zobrazuje viditelnost mezi objektem o výšce $8 \mathrm{~m}$ (předpokládaná výška dvoupodlažní budovy) a pozorovatelem o výšce $2 \mathrm{~m}$. Zobrazen je tak do jisté míry idealizovaný stav, kdy pozorovatel lokálně hledá místo s vhodným výhledem. 


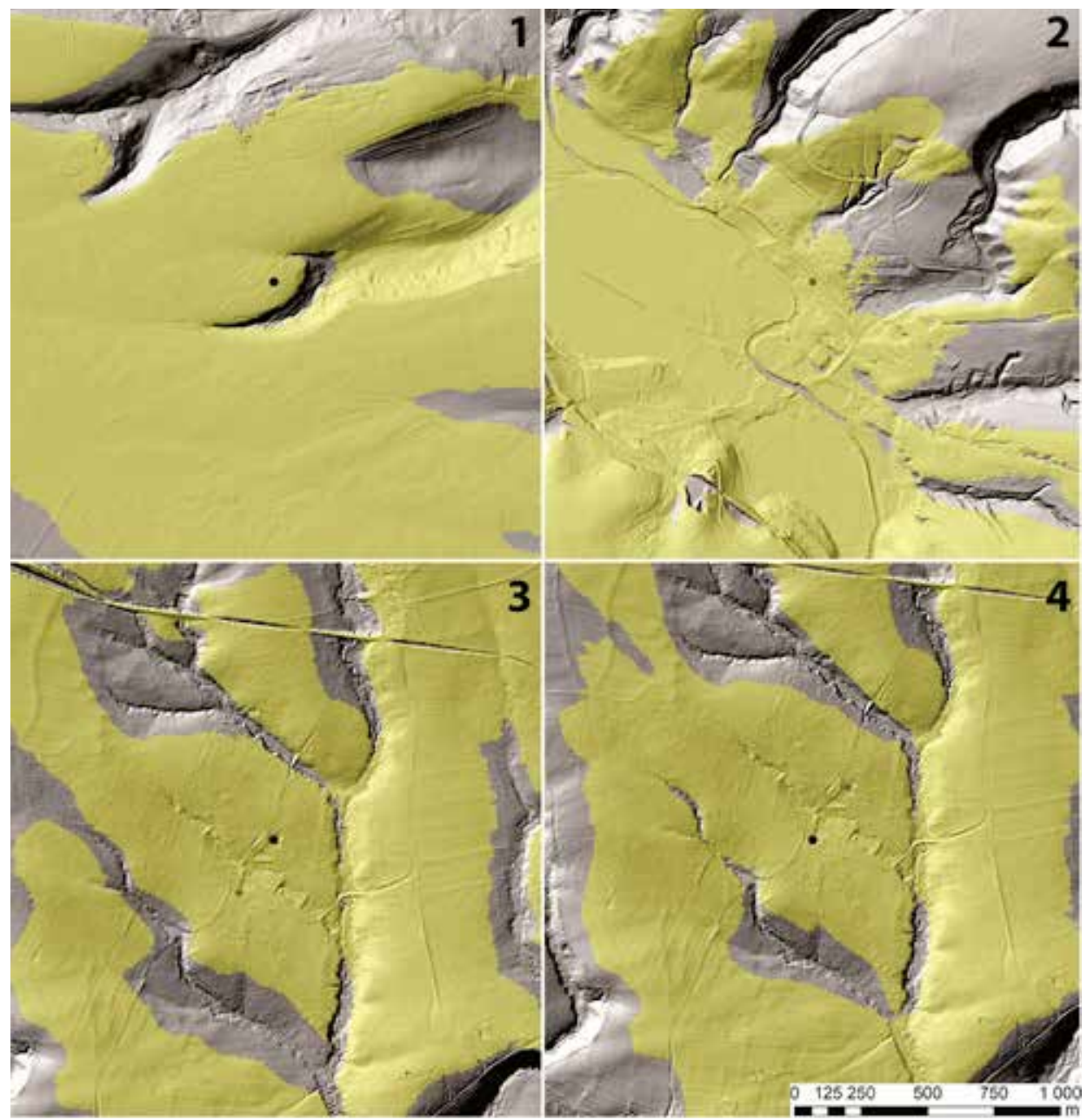

Obr. 13. Viditelnost okolí z vybraných dvorů v rovinatém terénu. Žlutě - viditelné polohy. 1 - Svídna (Drnek); 2 - Rinthof (Plasy); 3 - Trocnov - Mikšùv dvorec; 4 - Trocnov - Žižkův dvorec. Podkladová data Č́́ZK.

Abb. 13. Sichtbarkeit der Umgebung von ausgewählten Höfen in ebenem Gelände. Gelb - sichtbare Lagen. 1 - Svídna (Drnek); 2 - Rinthof (Plaß); 3 - Trocnov - Herrenhof von Mikeš; 4 - Trocnov - Herrenhof von Žižka. Unterlagendaten des Tschechischen Amtes für Landesvermessung und Kataster.

(srov. Brych 1998, XLIX). Hlavním účelem věžové stavby mohla být sociální diferenciace dvora od nižších kvalitativních úrovní usedlostí. Obytnou i skladovací složku snadno mohly zastoupit dokumentované vícedílné domy a špýchary. Věžovitá stavba nebyla nutností, ale její zbudování patrně bylo aktem s promyšlenou symbolikou, která měnila společenské postavení vlastníka či správce dvora. Takové areály přináší informaci o jinak velmi složitě poznávaných vrstvách na pomezí šlechty a poddanstva - o svobodné i nesvobodné klientele, jejímž živobytím byla bud' správa velmi malého statku, nebo zajištění produkce pro svého seniora. I sem můžeme klást přesah termínů municio a propugnaculum (druhého především). Definitivní verdikt leží nejen na budoucím systematickém archeologickém výzkumu modelově představených lokalit, ale také v jejich další interpretaci v kontextu práce historiků. 


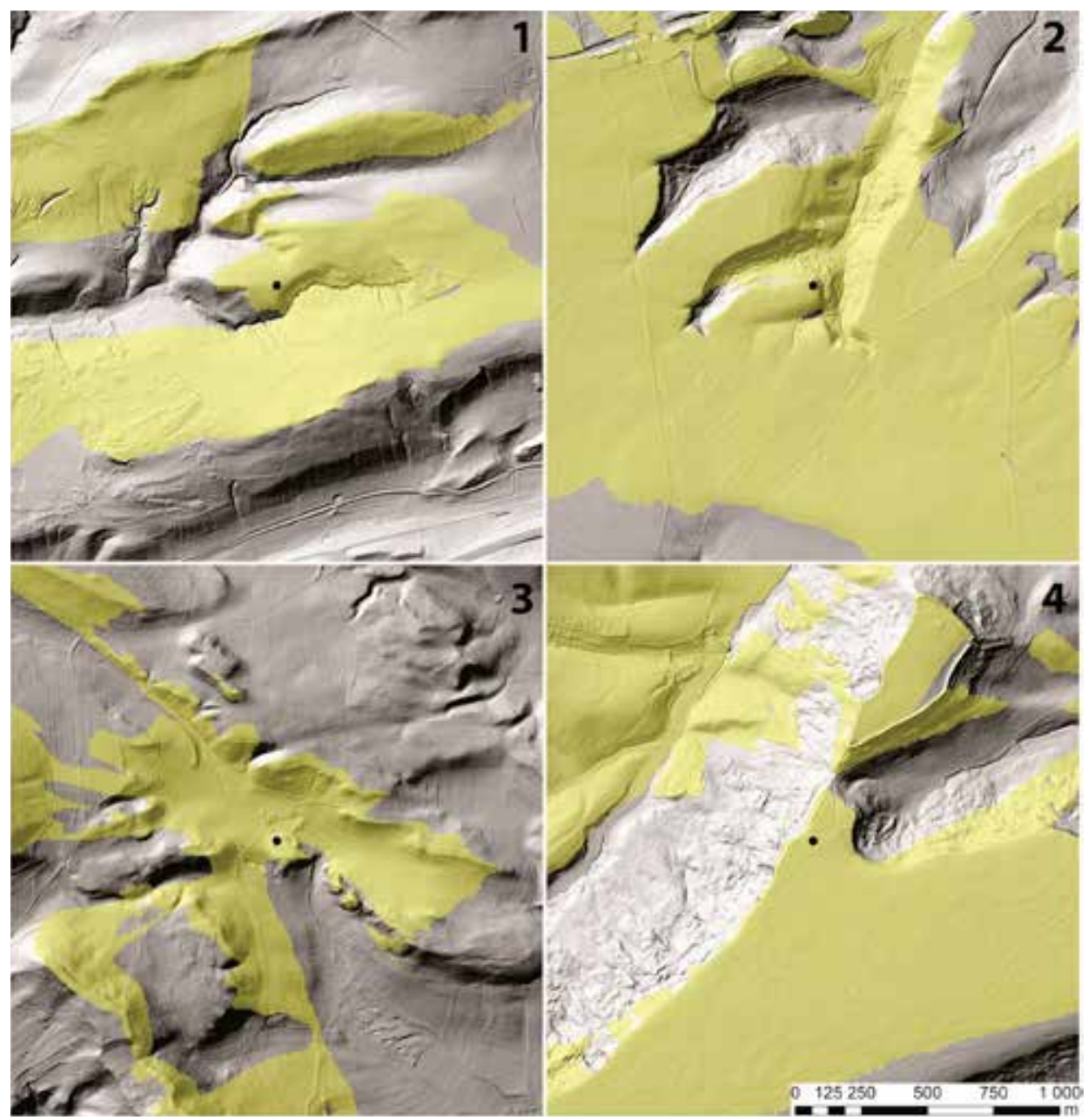

Obr. 14. Viditelnost okolí z vybraných dvorů ve členitém terénu. Žlutě - viditelné polohy. 1 - Kozinec (Beroun); 2 - Staré Zámky (Libušín); 3 - Lina (Vrbička); 4 - Rychvald (Kozojedy). Podkladová data ČÚZK.

Abb. 14. Sichtbarkeit der Umgebung von ausgewählten Höfen in gegliedertem Gelände. Gelb - sichtbare Lagen. 1 - Kozinec (Beroun); 2 - Staré Zámky (Libušín); 3 - Lina (Vrbička); 4 - Rychvald (Kozojedy). Unterlagendaten des Tschechischen Amtes für Landesvermessung und Kataster.

\section{Od formální struktury ke společenské interpretaci}

At’ už se přikloníme k libovolné interpretaci staveb uvedeného spektra, při shromáždění podkladů vidíme, že celková rozmanitost sídelních forem na pomezí dvorce, dvora a vrchnostenského sídla je vyšší, než se mnohdy uvádí. Zasahuje také širší časový rámec a dokážeme najít konkrétní společenské kategorie, ke kterým dané sídelní formy s vysokou mírou pravděpodobnosti přiřadit. Nesnadná archeologická zachytitelnost některých areálů je nepř́ijemným faktem, avšak i při stávající úrovni znalostí lze vyvodit jasný závěr, že budování sídel mladšího středověku vychází z hluboké starší tradice stavby dvorců raného středověku (srov. Laval 2013). Díky popsaným lokalitám a nastíněným vysvětlením se poněkud rozkládá dosud užívaná definice 
menších sídel, která je staví výlučně do těsného kontaktu s vesnickým zázemím a vyžaduje přítomnost opevnění. Terminologii bude třeba přinejmenším poupravit, protože za „hrádky“ bychom uvedená osamocená sídla označovali těžko (srov. Nekuda-Unger 1981, 6; Plaček 2008, 210-214) a „tvrz“ je obecně přijímaným pojmem jen v kontextu hrazeného sídla. V diachronním pohledu přirozené uspořádání dvorců raně středověkého období neustoupilo novým formám jako přežité, ale minimálně v podobě uvedených modelových prŕíkladů prostupovalo do mladšího středověku.

Pohybujeme se v prostředí nápravníků, klientů a rychtářů, vrchnostenských úředníků, kteří se svým postavením často prolínali se skupinou nejnižší rodové šlechty, z jejíchž řad se často rekrutovali. I když se u nás pravá ministerialita vyskytuje omezeně (Franc 2011, 116-122; Kubů 1997), takto snad identifikujeme její tuzemské reflexe, respektive obdobné řešení totožných potřeb - delegovat praktickou správu součástí větších panství na nižší úrovně. Fakt, že většina příkladů dvorů stojí osamoceně, není pravděpodobně dán tím, že by šlo o standard, ale že zachování podobných objektů v žijícím intravilánu vyžaduje výjimečně příznivou shodu okolností.

Př́i zamýšlení nad touto interpretací vzpomeňme na význam vertikálních struktur pro středověkou společnost (Reichertová 1961, 600; Šimůnek 2010, 207; Laval 2016) i na tzv. bergfrity českých hradů, které s útočištěm lze ztotožňovat pouze v omezené míře a sloužily spíše jako symbolická vyjádření vrchnostenské moci (Klápště 2005, 125; Mařík 2015; Zeune 2001, 11-12). Podobné symbolické a reprezentativní funkce v kontextu českých vesnic mohly plnit věžovité budovy ve dvorech, mechanicky interpretované jako sýpky. Patrové stavby obecně byly ve středověkém vesnickém prostředí výlučným znakem elit. I když se nemusí jednat př́ímo o věžovité budovy; samotná prrítomnost patra byla zcela specifická bez ohledu na typ objektu. Přestože ani některé tvrze - tedy jasně elitní stavby - neměly věžovitý charakter, o přízemní budovy šlo v mladším středověku (13.-15. století) naprosto výjimečně a samotná hmota patrové stavby musela jasně vystupovat z běžné produkce, nepočítáme-li stavby sakrální. Takové objekty rozhodně nelze srovnávat například s polopatry vystavěnými nad komorovými díly domů (Vařeka 2004, 238-267) a podstatné hmotové rozdíly shledáváme i oproti špýcharům, jak bylo zmíněno výše.

Historický pojem $d v u ̛ r^{11}$ sám o sobě mohl implikovat spíše periferní stránku aristokratického života a nemusel být vždy spojován přímo s osobou vlastníka. Proto pokud se setkáváme s tímto pojmem v kontextu málo známých predikátů, jsme vždy na pochybách, jakou sociální kategorii vlastníka/obyvatele si máme k objektu přiřadit. Byl to nápravník, svobodník, dvořák, šoltys, šafář, rychtáŕ, měšt’an nebo jen bohatý rolník? Nebo to byl skutečný panoš, miles, man či vladyka? At' už to byl kdokoli z nich, je to formální struktura dvora, která nám může napovědět mnohé o společenské úloze, kterou jeho představený sehrával. Od pozdního 15. století se vymezuje specifická typologická skupina dvorů, která je nedílně svázaná s drobnými sídly, a nejpozději tehdy se stalo propojení hmoty dvora a sídla dostatečným symbolem sociálního vymezení, i když i tehdy vznikají nápadně výstavné věžovité objekty sloužící spíše jako historizující odznaky moci. ${ }^{12}$ Starší, stř̌edověký poplužní dvůr naproti tomu nebyl po formální stránce vyloženě výstavným a dominantním prvkem. Jsme někdy na vážkách, jak část objektů dvorů odlišit od zbylých vesnických usedlostí. Hledaným klíčem mohou být diskutované věžovité stavby, které nacházíme $\mathrm{v}$ reliktech některých dvorů a nepřímo zachycené také $\mathrm{v}$ ostatních typech pramenů. Zmínky o přípustnosti konkrétních typů staveb, například v Saském zrcadle, nemusí nutně vyjadřovat jen právní omezení, ale mohou reflektovat přijímané omezení sociálně-symbolické. Věže do výšky třech podlaží a ohrazení do výšky muže na koni byla zjevně brána jako přípustná míra stavebního vyjádření nejširších vrstev nobility a svobodných, nebot' jejich stavba měla generální pardon bez nutnosti svolení jejich výstavby královským sudím (Aufgebauer

11 Zde mám pod tímto pojmem na mysli i alternativy a jazykové varianty užívané v historických pramenech.

12 Na mysli mám např. objekty výstavných věžovitých tvrzí, jako jsou Melechov, Tuchoraz i mladši Golčův Jeníkov, které nesly silné militární znaky, ale v praxi byly téměř nehajitelné. 
1998, 129). ${ }^{13}$ Výška ohrazení obyčejných dvorců podle Lex Salica přitom měla být „,vzrostlému muži po bradu či prsa“. Existoval též jasný rozdíl ve vnímání oplocení (sepis), vyššího ohrazení (tunimus) a hradby (Macháček 2008, 611; viz též diskuse o „týnech“ in: Smetánka 1978). Že bylo společenské prostředí systematizováno pomocí artefaktů, je nepochybné, a proto konkrétní typizované stavby mohly snadno sloužit jako prostředky sociálního a kulturního vyjádření (Kühtreiber 2014, 39-40).

Předložená analýza dvorů bohužel postrádá jasnější chronologické ukotvení, což ale odpovídá stávajícím znalostem. Většina diskutovaných reliktů se týká dvorů zaniklých počátkem nebo v průběhu 15. století, avšak díky ikonografickým pramenům je zřejmé, že ani dvory přežívající do 16. století svou podobu zásadním způsobem nezměnily, pokud si to nevyžádaly nové okolnosti (např. změna majitele). Významný přerod do počátku 17. století ostatně nepozorujeme ani v podobě vesnických usedlostí, které mají s menšími poplužními dvory mnoho společných znaků. Hlavní změnou je nahrazení dýmné jizby světnicí a související vznik černé kuchyně (Vařeka 2004, 256; Vařeka-Frolec 2007, 280-281). V poněkud retardovaném prostředí Rokycanska sice k nástupu jinde standardního trojdílného domu dochází až v 16. století, a v Rovném je proto dvůr zřetelně odlišný od zbylé zástavby jako jediná mohutnější stavba ve vsi vyjma paláce tvrze (Vařeka 2014; Novák-Vařeka 2016), podobný příklad bychom ale jinde hledali stěží a dvůr svou podobou obvykle ze standardních konceptů nevystupuje, pouze se liší dimenzemi (Kuna a kol. 2015, 301-304). Samozřjejmě toto neplatí pro mohutné dvory klášterní a velkopanské, které tak říkajíc predikovaly novostavby dvorů podnikatelské šlechty 16. století a byly tomu uzpůsobeny i formálně.

V průběhu raného novověku lze pozorovat obecnou a zřetelnou tendenci ke srůstání rozptýlených budov dvora do uzavřeného celku, který často pohltil i starší sídlo. Takové útvary mají málo společných charakteristik se starší situací a zahrnuté sídlo se obvykle proměňuje v neopevněnou pohodlnou vilu, volně provázanou s ostatními provozy. Samostatně stojící stavby zámků ležící mimo organismus dvorů se staly alternativním řešením a kvalitativně jiným stupněm sídel. Odlišné byly též dvory v prostř̌edí podnikatelských velkostatků, plánovitě zakládané na zelené louce, které se přímo nevázaly na vesnické osídlení. Ty se vrchnostenským sídlům svou funkcí a podobou natolik vzdálily, že přestává být možné je chápat jako typologickou variantu dvorců. Staly se svébytným jevem, který směřoval k novověké specializaci a velkovýrobě. Ne nadarmo je tato doba označována jako ,protokapitalistická“ (Čechura 1992), čemuž nutně musí odpovídat i zjištované krajinné komponenty. Podobný statut zaujímaly i tzv. šosovní dvory v majetku měst a měštanů, které opět spadaly do ekonomicky odlišně formovaného prostředí (Kovář 2011, 13). Dvory velkostatků někdy obsahovaly jen dočasné, dobře vybavené byty, užívané panstvem na cestách (tamtéž, 46).

Celý komplex změn navazujících v 17. století - od rozšíření počtu pracovníků dvora v souvislosti se stále náročnějšími robotními povinnostmi (Rameš 2005, 237-238) přes definitivní ukotvení lokálního trhu (Čechura 2008, 181-199) až k vymizení opevněných sídel a nástupu utilitárních opevnění aktivovaných pouze v čase potřeby - se formálně podepsal i na stavbách a účelu dvorů všech kategorií. Tehdy často přestávaly plnit funkci vrchnostenských sídel a původní symbolika zcela vyhasla.

13 „Man darf ohne die Erlaubnis des [zuständigen königlichen] Richters weder eine Burg bauen noch eine Stadt mit Planken oder mit Mauern befestigen, noch Wall oder Wettertürme innerhalb eines Dorfes errichten... Man darf [jedoch] ohne seine Erlaubnis mit Holz oder Steinen drei Stockwerke übereinander bauen, eins in der Erde, die anderen zwei darüber, vorausgesetzt, daß man in dem untersten Stockwerk ein Knie hoch über der Erde eine Tür hat. Man darf auch ohne weiteres einen Hof mit Zäunen oder mit Pfählen befestigen oder mit Mauern, die so hoch sind, wie ein Mann, auf einem Rosse sitzend, reichen kann. Zinnen und eine Brustwehr dürfen [aber] nicht daran sein." (Aufgebauer 1998, 129). Ve volném překladu: „Nikdo nesmi bez povoleni [ustaveného královského] sudiho ani vybudovat hrad, ani opevnit mésto palisádou nebo zdi, ani zř́dit hradbu nebo zvonici na vsi... Müže [nicméně] z kamene či dřeva tři podlaži vystavět jedno nad druhým, prvni na zemi, zbylé dvě nad ním, pokud dveře budou v nejnižšim patre ve výši kolen. Je rovněž povoleno opevnit dvưr ploty či kủly nebo zdi, vysokými tak jako muž sedicí na koni. Nesmi [ale] na něm být ochozy ani cimbuři." 


\section{Závěr}

Je nápadné, že elity užívají několika prostředků k sociální identifikaci. Všechny jsou založeny na vydělení se z běžné komunity pomocí sdílených symbolických znaků. Takové vydělení může v př́ípadě staveb probíhat horizontálně (vzdálenost, př́ikopová a valová ohrazení, hradby, zdi, vodní plochy, přírodní bariéry), vertikálně (převýšená místa, věže, přírodní dominanty) i formálně (architektonické a umělecké prvky, stavební materiál, proporce). Všechny tyto prostředky pracovaly s pohybem v prostoru a s vizuálním účinem, který zachycoval podstatu elity. $\mathrm{S}$ proměňující se společností, která se stávala stále komplexnější a více se upínala $\mathrm{k}$ ideálu než ke skutečné materiální formě, se vývoj ubíral směrem od explicitních vyjádření ve středověku k novověkým náznakům jednotlivých významů. I přestože obvykle nepochybujeme o zařazení pozdně gotických a renesančních staveb ve dvorech do kategorie „vrchnostenské sídlo“, u podobných areálů ve středověku je třeba určité opatrnosti. V podstatě je zřejmé, že pokud byl skutečně středověk významově více názorný, musel dvůr obsahovat velmi dominantní stavbu, pokud chtěl vlastník dostatečně reprezentovat své postavení vůči tehdejší společnosti. V této perspektivě by diskuse nad středověkými dvory s věžovitou stavbou patrně vyplynula tak, že bychom objekty jako Rovný, Svídna nebo Rinthof v Plasích mezi vrchnostenská sídla i nadále řadit neměli, nebot' nemáme doklady dostatečného počtu znaků, které by prokazovaly vydělení jejich obyvatel mimo vesnickou komunitu. Rychvald, Kozinec u Berouna, trocnovské dvorce a Hrnčíře by pak ležely na pomyslném ostří, za nímž bychom bezpečně obhájili pozici Starých Zámků u Libušína, Liny, Bedřichova Světce, Džbánku nebo Třebekova. Samožrejmě není to jediná možnost a měli bychom se nadále věnovat výzkumu těchto lokalit, aby byla v budoucnu nalezena pevnější kritéria. Prozatím se přikláním k tomu, že existovala jistá mezní sociální skupina, která nebyla přímo vrchností, ale byla jejím nástrojem při komunikaci s místními komunitami. K jejímu postavení připadalo i právo částečného užívání vrchnostenské symboliky, reprezentované věžovitými stavbami.

Otázkou zůstává, jaké okolnosti dovolily povznést i dosud na okraji stojící objekty ve dvorech mezi vrchnostenská sídla a jejich mnohdy nepř́liš majetné stavebníky mezi erbovní šlechtu. Pokud totiž něco zprvu odlišovalo např́iklad měšt’ana od drobného šlechtice, nebyla to jeho osobní výbava, ale stavební kultura, která byla v městě ,zahrnující“ (potlačující rozdíly), kdežto u venkovských sídel „,vymezující“ (zdůrazňující sociální bariéry). Pokud měšt’an usiloval o redefinici sociální role a zařazení mezi šlechtické stavy, musel tento symbolický rámec přijmout a reflektovat, a to stavbou či koupí odpovídající rezidence, či alespoň jejího symbolického obrazu. Dosud nevíme, jaké překážky mohly být kladeny na nejnižší elity při výstavbě jejích sídel ve dvorech ve vesnickém prostředí, pokud byly stále vázány služebným vztahem k seniorovi, a nakolik jim právě nová sídla pomáhala se v tomto vztahu dále emancipovat. Vybudování věžovité stavby - bez ohledu na její praktickou funkci - mohlo být prvním krokem k takové emancipaci.

Publikační výstup vznikl za podpory projektu Archeologický informační systém České republiky - druhá generace (AIS-2; CZ.02.1.01/0.0/0.0/16_013/0001439).

\section{Literatura}

ANDERLE, J.-ROŽMBERSKÝ, P.-ŠVÁBEK, V., 1993: Výsledky povrchového průzkumu cisterciáckých dvorů na Plzeňsku - Ergebnisse der Oberflächenerkundung von Zisterzienserhöfen in der Gegend Plzeň, CB 3, 261-270.

ANDERLE, J.-ŠVÁBEK, V., 1992: Tvrze v rokycanském okrese, 2. část, Sborník Muzea dr. B. Horáka v Rokycanech 4, 3-44.

ANDERLE, J. a kol., 1989: Týnecký cyklus vedut - Der Vedutenzyklus von Týnec, CB 1, 335-345.

AUFGEBAUER, P., 1998: Burg - Kloster - Stadt. Zur mittelalterlichen Geschichte des südlichen Niedersachsen, Concilium medii aevi 1, 123-174. 
BRYCH, V., 1998: Hmotná kultura středověké tvrze v Čechách. In: Encyklopedie českých tvrzí. I. díl (A-J), XLVII-LXXXIII. Praha.

BŘICHÁČEK, P., 1993: Dvorec u Poněšic - Dobřejovic (okr. Č. Budějovice) - Gehöft bei Poněšice - Dobřejovice (Bez. Böhm. Budweis), CB 3, 211-216.

BUBENÍK, J.-VELÍMSKÝ, T., 1986: Archeologický výzkum polykultrurní lokality u Jenišova Újezda, Archeologické studijní materiály 15, 42-49.

BURAČINSKÁ, M., 2008: Zaniklá ves Kokot - The Deserted Village of Kokot. In: Vařeka, P. a kol., Archeologie zaniklých středověkých vesnic na Rokycansku 2 - Archaeology of Deserted Medieval Villages in the Rokycany-Region (West Bohemia) 2, 53-116. Plzeň.

ČECHURA, J., 1992: Dominium Smiřických - protokapitalistický podnikatelský velkostatek předbělohorských Čech - Das Dominium der Familie Smiřický - ein protokapitalistisches Grossgrundbesitzerunternehmen Böhmen in der Zeit vor der Schlacht auf dem Wiessen Berg, ČČH 90, 507-536.

- 2008: České země v letech 1526-1583: První Habsburkové na českém trůně I. Praha.

DUDKOVÁ, V.-ORNA, J.-VAŘEKA, P. a kol., 2008: Hledání zmizelého. Archeologie zaniklých vesnic na Plzeňsku. Plzeň.

DURDÍK, T., 1997: Vrbička, Výzkumy v Čechách 1993-1995, 321-322.

DURDÍK, T.-KRUCKÝ, M., 2003: Zpráva o archeologické akci C-TX-200305359. Rkp. ulož. v archivu ARÚ AV ČR, Praha, v. v. i.

FRANC, J., 2011: Chebsko a ministerialita. Dvojí identita regionu. Rkp. disertační práce, ulož. na Katedře historie FF UP v Olomouci.

GOJDA, M. a kol., 2010: Archeologie krajiny a sídel na Podřipsku. Výzkum středověkého ohrazeného areálu v Ledčicích - Archaeology of the landscape and settlement around Říp Hill. Investigation of a medieval moated site (enclosure) at Ledčice, AR LXII, 259-292.

GRAUS, F., 1957: Dějiny venkovského lidu v Čechách v době předhusitské II. Dějiny venkovského lidu od poloviny 13. stol. do roku 1419 - L'histoire de la paysannerie en Bohême à l'époque pré-hussite II. Praha.

HEBER, F. A., 2012: České hrady, zámky a tvrze. Díl 4. Střední Čechy. Praha.

HRUBEC, I., 1971: Výskum zaniknutej dediny Dolný Poltár - Grabungen in der Dorfwüstung Dolný Poltár, AR XXIII, 69-79.

CHOTĚBOR, P., 1992: Tvrze v ikonografických pramenech - Die Festen in den ikonographischen Quellen, AH 17, 177-187.

CHOTĚBOR, P.-SMETÁNKA, Z., 1985: Panské dvory na české středověké vesnici - Herrenhöfe im mittelalterlichen Dorf Böhmens (13.-16. Jahrhundert), AH 10, 47-65.

JUSTOVÁ, J., 1985: Archeologický výzkum na libickém předhradí v letech 1974-1979 (Předběžná zpráva) - Excavations on the Libice bailey (Vorburg) during the period 1974-1979 (A preliminary report), AR XXXII, 241-264.

KLÁPŠTĚ, J., 1994: Pamět' krajiny středověkého Mostecka - Das Landschaftsgebiet Brüx als Zeuge des Mittelalters. Most.

- 2005: Proměna českých zemí ve středověku. Praha.

KOLEKTIV 1998-2005: Encyklopedie českých tvrzí. Praha.

KOVÁŘ, D., 2011: Tvrze, hrady a zámky Českobudějovicka. České Budějovice.

KUBU゚, F., 1997: Štaufská ministerialita na Chebsku. Cheb.

KUNA, M. a kol., 2015: Archeologický atlas Čech. Vybrané památky od pravěku do 20. století. - Archaeological Atlas of Bohemia. Selected sites from prehistory to the 20th century. Praha.

KÜHTREIBER, T., 2004: Wirtschaft im Schatten der Burg. Die Bedeutung von mittelalterlichen Wirtschaftsstrukturen im unmittelbaren topographischen Kontext von Burgen in Ostösterreich - Economic activity in the shadow of the castle, Château Gaillard 21, 163-177.

- 2014: The Investigation of Domesticated Space in Archaeology - Architecture and Human Beings. In: Dwellings, Identities and Homes. European Housing Culture from the Viking Age to the Renaissance (Kristiansen, M. S.-Giles, K., edd.), 39-51. Højbjerg.

KYPTA, J. a kol., 2012: Osamocený dvůr s opevněným sídlem v pozdním středověku: Rychvald u Dřevíče (okr. Rakovník) a jeho analogie - An isolated Late Middle Ages farmyard with a fortified residence: Rychvald near Dřevíč (Central Bohemia) and its analogies, AR LXIV, 549-570.

LAVAL, F., 2013: Archeologie tvrze v českých zemích: K počátkům středověkých opevněných sídel. Rkp. disertační práce, ulož. v Ústavu pro archeologii FF UK v Praze.

- 2016: Co je kostel? K počátkům šlechtických sídel českého středověku - On the beginnings of aristocratic seats in medieval Czech lands, AR LXVIII, 47-90.

LISSEK, P., 2006: Středověká sladovna z Jenišova Újezdu. In: Archeologické výzkumy v severozápadních Čechách v letech 1998-2002 (Hlavová, J.-Sýkora, M., edd.), 89-114. Most. 
MACHÁČEK, J., 2008: Středoevropský model a jeho archeologické testování - The Central European Model and its Archeological Verification, $\breve{C} \breve{H}$ 106, 598-626.

MAŘÍK, T., 2014: Bergfrity českých hradů. Rkp. diplomové práce, ulož. na KAR FF ZČU.

MEDUNA, P., 2006: Hrnčíre, zaniklý dvůr oseckého kláštera - Hrnčíře, der untergegangene Hof des Klosters in Osek, CB 10, 245-256.

- 2008: K stavební podobě raně středověkých „curtes“. In: Archeologické výzkumy v severozápadních Čechách v letech 2003-2007. Sborník k životnímu jubileu Zdeňka Smrže (Černá, E.-Kuljavceva Hlavová, J., edd.), 269-276. Most.

MUSIL, J.-NETOLICKÝ, P., 2016: Mezi vesnicí a vrchnostenským sídlem: dvory na středověkém Chrudimsku - Zwischen Dorf und Herrschaftssitz. Mittelalterliche Höfe in der Region Chrudim, AH 41, $211-228$.

NEKUDA, R., 2008: Stavební vývoj hospodářských staveb středověké vesnice na Moravě - Development of farm constructions in the medieval Moravian village, ŠZ AÚ SAV 43, 95-121.

NEKUDA, V.-UNGER, J., 1981: Hrádky a tvrze na Moravě. Brno.

NKP KLÁŠTER PLASY: Dostupné z: http://www.plasy.cz/turista/galerie/fotografie/nkp-klaster-plasy/, cit. 3. 10. 2018.

NOVÁK, D., 2016: České „tvrze“. Kritická analýza současného stavu poznání - Böhmische „Festen“: eine kritische Analyse des gegenwärtigen Erkenntnisstands, CB 16, 123-152.

NOVÁK, D.-VAŘEKA, P., 2015: Tvrze na Rakovnicku - Festen im Großraum Rakovník, AH 40, 507-533.

- 2016: A Late-Medieval Manor Farm in Rovný (Rokycany District, Pilsen Region) - Pozdně středověký hospodářský dvůr v Rovném (okres Rokycany, Plzeňský kraj), AH 41, 211-227.

PLAČEK, M., 2008: Ke vztahu sídel nižší šlechty a jejich hospodářského zázemí - Zur Beziehung zwischen den Sitzen des niederen Adels und ihrem wirtschaftlichen Hinterland, AH 33, 209-220.

POLLA, B., 1962: Stredoveká zaniknutá osada na Spiši (Zalužany). Bratislava.

PRINCOVÁ-JUSTOVÁ, J., 2000: Chalupovský manský dvůr v Libici nad Cidlinou. Archeologický př́spěvek k poznání stř̌edověké a raně novověké vsi Libice. Část I - Der Chalupov'sche Vasallenhof in Libice a. d. Cidlina. Archäologischer Beitrag zur Erkenntnis des mittelalterlichen und früh-neuzeitlichen Dorfes Libice. Teil I, CB 7, 241-254.

- 2002: Chalupovský manský dvůr v Libici nad Cidlinou. Archeologický příspěvek k poznání stř̌edověké a raně novověké vsi Libice. Část. II - Der Hof des Vasallenhauses „Chalupovský“ in Libice an der Cidlina. Archäologischer Beitrag zur Erkenntnis des mittelalterlichen und frühneuzeitlichen Dorfes Libice. Teil II, CB 8, 381-392.

RAMEŠ, V., 2005: Slovník pro historiky a návštěvníky archivů. Praha.

REICHERTOVÁ, K., 1961: K problematice výzkumu středověké tvrze - Ein Beitrag zur Frage der Landsitzenforschung, PA LII, 599-608.

ROUS, P., 2010: Dvory v okolí Havlíčkova Brodu a možnosti jejich zkoumání, Havlíčkobrodsko 24, 20-39.

- 2011: Středověké a raně novověké dvory v okolí Havličkova Brodu, Havlíčkobrodsko 25, 162-168.

ROŽMBERSKÝ, P., 2008: Dvory plaských cisterciáků. Zapomenuté hrady, tvrze a místa 21. Plzeň.

RYKL, M., 2008: Obytná část dispozice středověké tvrze v Čechách - Der Wohnteil der mittelalterlichen Festenanlage in Böhmen, Svorník 6, 33-68.

SANKOT, J.: Středověká tvrz a vsi pod Farskou skálou. Dostupné z: http://www.chvalenice.cz/obec-107/z-historie-obce-1/kapitoly-z-historie/zajimava-mista-v-okoli/stredoveka-tvrz-a-vsi-pod-farskou-skalou/, cit. 23. 11. 2018.

SEDLÁČEK, A., 1882-1927: Hrady, zámky a tvrze Království českého. Praha.

SMETÁNKA, Z., 1978: Diskuse o problematice sídlišt’ typu „Týn“, AR XXX, 210-212.

- 1988: Život středověké vesnice. Zaniklá Svídna. Praha.

SMETÁNKA, Z.-KLÁPŠTĚ, J., 1981: Geodeticko-topografický průzkum zaniklých středověkých vsí na Černokostelecku - Geodetical-topographical survey of deserted medieval villages in the Kostelec-nad-Černými-Lesy region, PA LXXII, 416-458.

SYNEK, J., 1998: O jednom málo známém tvrzišti v okolí Berouna, Hláska 9, 45.

ŠIMU゚NEK, R., 2010: Hrad jako symbol v myšlení české středověké šlechty - The Castle as a Symbol in the Consciousness of Czech Medieval Aristocracy, ČČH 108, 185-219.

VARHANÍK, J., 2018: K existenci sýpky na hradě ve středověku - Zur Existenz von Speichern auf mittelalterlichen Burgen, AH 43, 385-399.

VAŘEKA, J.-FROLEC, V., 2007: Lidová architektura: Encyklopedie. Praha.

VAŘEKA, P., 2004: Archeologie středověkého domu I: Proměny vesnického obydlí v Evropě v průběhu staletí, 6.-15. století. Plzeň. 
- 2008: Zaniklý dvůr Nevězeň. In: Vařeka, P. a kol., Archeologie zaniklých středověkých vesnic na Rokycansku 2, 117-125. Plzeň.

- 2014: Zaniklá středověká a časně novověká ves Rovný na Zbirožsku (okr. Rokycany) - Das untergegangene mittelalterliche und frühneuzeitige Dorf Rovný in der Region Zbiroh (Bez. Rokycany), AZČ 7, 131-143.

- 2014a: Zaniklý pozdně středověký dvůr u Olešné na Rokycansku - Untergegangener spätmittelalterlicher Hof bei Olešná im Landkreis Rokycany, AZČ 8, 134-143.

VAŘEKA, P. a kol., 2006: Archeologie zaniklých středověkých vesnic na Rokycansku I - Archaeology of Deserted Medieval Villages in the Rokycany-Region (West Bohemia) I. Plzeň.

- 2008: Archeologie zaniklých středověkých vesnic na Rokycansku II - Archaeology of Deserted Medieval Villages in the Rokycany-Region (West Bohemia) II. Plzeň.

VELC, F., 1904: Soupis památek historických a uměleckých v království Českém od pravěku do počátku XIX. století. XX: Politický okres Slánský. Praha.

WHEATLEY, A., 2004: The Idea of the Castle in Medieval England. Woodbridge.

ZEUNE, J., 2001: Die Burg als Symbol von Herrschaft und Macht. Gedanken zum Nachdenken - Teil II, Burgen und Schlösser in Bayern, Österreich und Südtirol 2001/1, 9-14.

ŽIŽKA, J., 1999: K podobě předbělohorských hospodářských budov - Zu der Gestalt der Wirtschaftsgebäude aus der Zeit vor der Schlacht am Weissen Berg, PSČ 13, č. 2, 23-29.

\section{Zusammenfassung}

\section{Höfe, Herrenhöfe oder Residenzen - zur Frage der sozialen Abgrenzung von Eliten im Mittelalter}

Bei der Untersuchung von Eliten nehmen unsere Erkenntnisse in beträchtlichem Maße ab mit der Qualität der Ausführung, die diese Obejekte erreichten. Ein nur wenig beschriebenes Kapitel sind somit mittelalterliche Fundstellen, die an der Grenze zwischen Residenz und Hof stehen und bisher nur völlig am Rande beobachtet wurden. Dabei taucht in letzter Zeit eine Reihe von dokumentierten Fundstellen auf, die dabei behilflich sein können, sich in der Problematik zu orientieren. Die Interpretationen sind vorerst relativ einseitig auf die ökonomische Seite solcher Fundstellen und auf ihr Verstehen als Wirtschaftshöfe ausgerichtet und widmen sich nicht allzu sehr der Repräsentations- und Residenzbedeutung der Bauten, die sich in den Höfen befunden haben konnten.

Obgleich die Interpretation von im Innern (oder in der Nähe) der Bebauung von Höfen gelegenen Turmbauten nicht eindeutig ist, ist es möglich, sich auf vergleichbare formale Merkmale der beschriebenen Objekte zu einigen. Obwohl die Freilegungen einiger Fundstellen und ihre Ausstattung mit Artefakten deutlich erkennbare Anzeichen für eine Interpretation liefern, schließen wir immer noch nicht aus, dass bei diesen Arealen die Wirtschaftsfunktion überwog und die architektonische Gestaltung des Hauptgebäudes einen rein symbolischen Wert hatte. Wenn wir die erwähnten Bauten nur als Speicher bezeichnen, sollten wir jedoch nicht nur ihre offensichtlich monumentalste Form im Rahmen der betreffenden Areale, sondern auch die bisherigen Kenntnisse über die Form von turmartigen Speichern nicht ignorieren. Es handelt sich dabei immer um Gebäude mit einer maximalen Ausdehnung von bis zu ca. $30 \mathrm{~m}^{2}$ und einer relativ einfachen Bauweise, die zum beobachteten Objekttyp mit einer bebauten Fläche im Umfang von ca. 40-100 $\mathrm{m}^{2}$ einen starken Kontrast bilden - beide Intervalle tun sich somit noch nicht einmal überschneiden. Eine eventuelle Lagerfunktion solcher Bauten schließt dabei nicht aus, dass das Gebäude als Residenz einer Obrigkeit diente, die einen Wohn-Repräsentationsraum enthält.

Dank der Auswertung ausgewählter Fundstellen und Quellen kann man zu der Interpretation tendieren, dass unsere Beobachtungen sich bisher nur in Andeutungen der erfassten Objektgruppe bewegten, die als Wirtschaftseinheiten mit repräsentativem turmartigen Gebäude konzipiert wurden. Das Gebäude konnte partiell auch eine Lagerfunktion haben, die den Wohncharakter anderer Teile des Baues nicht ausschließt, was archäologische Funde von Lagerräumen mit Überresten von Halmfrüchten im Innern des Kernbereichs der Sitze auch belegen. 
Der Hauptzweck eines turmartigen Gebäudes war offenbar die Unterscheidung eines Hofes von Anwesen eines qualitativ niedrigeren Niveaus. Die Wohn- und Lagerkomponente konnte leicht auch durch die dokumentierten mehrteiligen Häuser und Speicher repräsentiert werden. Ein turmartiger Bau war keine Notwendigkeit, sondern ihr Ausbau war ein Akt durchdachter Symbolik, welche die soziale Stellung des Eigentümers oder Verwalters eines Hofes wesentlich veränderte. Solche Areale liefern Informationen über ansonsten sehr kompliziert erkannte soziale Schichten an der Grenze zwischen Adel und Untertanen - über freie und unfreie Klientel, deren Lebensunterhalt entweder aus der Verwaltung eines sehr kleinen Anwesens, oder der Sicherung der Produktion für ihren Senior bestand. Auch hierhin können wir die Überlappung der Termini municio und propugnaculum legen (vor allem des zweiten). Das definitive Verdikt hängt ab von einer künftigen systematischen archäologischen Untersuchung der modellhaft vorgestellten Fundstellen, aber auch von ihrer weiteren Interpretation im Kontext der Arbeit der Historiker.

Mgr. David Novák, Ph.D., Archeologický ústav AV ČR, Praha, v. v. i., Letenská 123/4, 11801 Praha 1, Česká republika,novak@arup.cas.cz 
